\title{
Citizens-based Assessment of a Renovation Facilitating Policy in Urban Deteriorated Areas: An Ordinal Logistic Regression Model
}

Saeed Najd Ataei Sarkarabad

University of Kurdistan, Department of Urban Planning and Design

sna85urb@gmail.com

Elahe Rezaei

Islamic Azad University, Science and Research Branch, Tehran, Department of Urban Planning

ela87urb@gmail.com

Kyoumars Habibi

University of Kurdistan, Department of Urban Planning and Design

habibi_ki@yahoo.co.uk

correspondence author concerning this article: University of Kurdistan, Pasdaran St, Sanandaj, Kurdistan, Iran, Postal Code: 66177-15175. 


\section{Abstract}

This study tested which latent factors exist that could significantly impact the citizens-based performance assessment of the Neighborhood Renovation Service Office (NRSO) which is a renovation facilitating policy. Two hundred residents of Urban Deteriorated Areas (UDAs) in Fallah \& Yaftabad neighborhoods, were interviewed by questionnaires. To analyze the outcomes of the questionnaires, first, an Exploratory Factor Analysis (EFA) for identifying underlying factors for assessment of the mentioned policy and subsequently Ordinal Logistic Regression (OLR) for modeling the factors concerning performance assessment were employed.

The residents who had more familiarity with the plans and policies evaluated the renovation office performance more positively. Also if NRSOs want to be assessed as more effective in their intervention they need to empower their interacting community's socioeconomic factor. The OLR model showed that the sense of place is another significant underlying factor in this regard. However, residency duration despite converging as a factor in EFA did not show any significant impact based on the OLR model.

Keywords: citizens-based assessment; renovation facilitating policy; Neighborhood Renovation Service Office (NRSO); Urban Deteriorated Areas (UDAs); Ordinal Logistic Regression (OLR)

\section{Resumen}

Este estudio probó qué factores latentes existen que podrían afectar significativamente la evaluación de desempeño basada en los ciudadanos de la Oficina de Servicios de Renovación de Vecindarios (NRSO), que es una política que facilita la renovación urbana. Doscientos residentes de áreas urbanas deterioradas (UDA) en los vecindarios de Fallah y Yaftabad fueron entrevistados mediante cuestionarios. Para analizar los resultados de los cuestionarios, primero se empleó un Análisis Factorial Exploratorio (EFA) para identificar los factores subyacentes para la evaluación de la política mencionada y, posteriormente, la Regresión Logística Ordinal (OLR) para modelar los factores relacionados con la evaluación del desempeño.

Los residentes que estaban más familiarizados con los planes y políticas evaluaron el desempeño de la oficina de renovación de manera más positiva. Además, si las NRSO quieren ser evaluadas como más efectivas en su intervención, necesitan potenciar el factor socioeconómico de su comunidad interactiva. El modelo OLR mostró que el sentido de lugar es otro factor subyacente significativo en este sentido. Sin embargo, la duración de la residencia a pesar de converger como factor en la EFA no mostró ningún impacto significativo según el modelo OLR.

Palabras clave: evaluación ciudadana; política de facilitación de la renovación; Oficina de Servicios de Renovación de Vecindarios (NRSO); Áreas urbanas deterioradas (UDA); Regresión logística ordinal (OLR)

\section{Resum}

Aquest estudi va provar quins factors latents existeixen que podrien afectar significativament l'avaluació d'acompliment basada en els ciutadans de l'Oficina de Serveis de Renovació de Veïnats (NRSO), que és una política que facilita la renovació urbana. Dos-cents residents d'àrees urbanes deteriorades (UDA) en els veïnats de Fallah i Yaftabad van ser entrevistats mitjançant qüestionaris. Per analitzar els resultats dels qüestionaris, primer es va emprar una Anàlisi Factorial Explorador (EFA) per identificar els factors subjacents per a l'avaluació de la política esmentada i, posteriorment, la Regressió Logística Ordinal (OLR) per modelar els factors relacionats amb l'avaluació de l' acompliment. 
Els residents que estaven més familiaritzats amb els plans i polítiques van avaluar l'acompliment de l'oficina de renovació de manera més positiva. A més, si les NRSO volen ser avaluades com més efectives en la seva intervenció, necessiten potenciar el factor socioeconòmic de la seva comunitat interactiva. El model OLR va mostrar que el sentit de lloc és un altre factor subjacent significatiu en aquest sentit. No obstant això, la durada de la residència malgrat convergir com a factor en l'EFA no va mostrar cap impacte significatiu segons el model OLR.

Paraules clau: avaluació ciutadana; política de facilitació de la renovación urbana; Oficina de Serveis de Renovació de Veïnats (NRSO); Àrees urbanes deteriorades (UDA); Regressió logística ordinal (OLR)

\section{Introduction}

Over 50 years of local and national authorities' endeavors on the renovation of UDAs $^{1}$ in Tehran with various policies, yet could not solve this problem properly (Abbaszadegan, 2010). The report of the CEO of Tehran Renovation Organization (TRO) about the status of UDAs showed after five-decade renovation intervention policies, still based on three criteria , 3268 hectares of Tehran have been determined as UDAs. These urban areas not only comprise $22 \%$ of urban land plots in Tehran but also have a population of about 15\% of that of Tehran, that is around 1.35 million people. Besides, 52 percent of neighborhoods are involved with UDAs in Tehran, that is 196 neighborhoods (Fatehelahi, 2016). Under the experience of previous policies; Neighborhood Renovation Service Office (NRSO), as an intervention policy with facilitation and participation approaches, is a relevantly novel practice in recent years which has reached some acceptable achievements (Afzali \& Sharifi, 2016), yet it needs more assessment to improve its performance and efficacy for the eradication of UDAs in Tehran.

Recent research has shown that citizens' effective participation, citizens-based assessment particularly, acts as an Achilles heel for the success of urban policies. Public participation is the most important part of any development process in cities (Abdollah et al., 2014). Especially in UDAs, the participation of residents should be intertwined with the intervention process (Hakim \& Roshanali, 2018). Although David Wilcox (1994) believed getting feedback from citizens is a pathway toward Effective Participation and questionnaire studies and survey can be excellent ways to start a participation process, he stated it is not enough. Also, Abdollah et al. (2014) stated that participation in the assessment of urban policies is one of the main pillars of full-scale participation. Moreover, performance assessment by citizens is one type

1. According to the resolutions of the Supreme Council of Urban Planning and Architecture of Iran in 2006, UDAs are urban blocks where over $50 \%$ of urban plot within them have three criteria as follow: 1- less than 200 square meters area, 2- unstable buildings with lack of structural system and 3-access to the street with a width of less than 6 meters (Azimi, 2016, p. 127). 
of performance assessment of urban intervention policies which not only helps to monitor the satisfaction level of the urban residents but also could play a pivotal role in the success of the urban policies in achieving their goals due to two reasons. First, the residents who are satisfied with the city policymakers' performance, do their citizenship duties with more confidence, and second, citizens are the only people who can understand their problems in depth (Afzali \& Sharifi, 2016).

The findings of several studies depicted that several variables are associating with citizens' assessment of urban participatory policies. One of these variables is household socio-economic condition. Ulbing (2008) discussed that household economic status, like income level or dependency burden, correlates with citizens' satisfaction with a policy. Furthermore, many scholars (Feng et al., 2020; Lancee \& Van de Werfhorst, 2012; Mather, 1941; Scharf et al., 2005; SEN, 1983) have pointed out that there is a rather strong association between households economic condition and their tendency to participate in urban policies and their level of positive feedback to these policies. These scholars have mentioned reasons like shame associated with the inability to live a decent life (SEN, 1983), their belief of their fruitless effect due to having fewer resources, and feeling of being degraded (Lancee \& Van de Werfhorst, 2012), which lead the less-wealthy households to less contribution in social and civic activities and consequently to rather less-positive assessment of the policies involving such contributions. Likewise, different researchers (Feng et al., 2020; Gesthuizen, 2006; Paulsen, 1991; Zhang \& Wu, 2017) have highlighted the positive correlation between the level of literacy and participation, or name it as one of the variables concerning participation (Font \& Navarro, 2013), or assessment of a policy satisfaction of citizens (Ulbig, 2008).

Another variable which some studies suggested could affect citizens' participation and that may influence their assessment of urban policies is their willingness to stay in the neighborhood. Wu (2012) find out that willingness to stay in a neighborhood associated with participation in community activities, although negatively. Hays \& Kogl (2007) find that residents who have strong neighborhood attachment are not necessarily more involved in formal neighborhood associations. Besides the willingness to stay, many scholars discussed the Sense of Community (SoC) and its connection to participation and urban policies assessment by citizens. McMillan \& Chavis (1986) in their article "Sense of Community: A Definition and Theory", proposed four criteria for defining sense of community (SoC): Membership (feeling of belonging), Influence (influencing on or being influenced by the neighborhood where the person is a member of), Integration and Fulfillment of Needs (reinforcement), and Shared Emotional Connection (shared history). Based on McMillan \& Chavis's definition, one impression of SoC may be, how much a person Likes the place where he or she lives and fell Belonging to it. Scholars like Talò et al. (2014), Anderson (2010), and Chavis 
\& Wandersman (1990) posited that there is a significant and positive relationship between SoC and participation; which activates the community's internal human resources, solves problems, promotes social empowerment(Talò et al., 2014), and above all creates trust in policies (Anderson, 2010), including urban policies.

Some community-level characteristics like Duration of residence also have important contextual effects on individuals' participation in civic activities (Kang \& Kwak, 2003). Owing to Length of residence has been found to correlate with various features of community attachment, including local friendship and community interest (Kang \& Kwak, 2003); and influencing individuals' local social bonds and associational ties (Kasarda, J. D.; Janowitz, 1974); It is expected that this parameter would function to enhance individuals' participation (Kang \& Kwak, 2003). However, some scholars believe that the lower level of citizens' participation is affected by the overall length of the period of residence ( $\mathrm{Wu}, 2012)$.

Some variables could serve as indicators that reflect the performance of a participatory policy. Citizens' personal and direct contact with participatory urban policies, like NRSOs, is one of them. Font \& Navarro (2013) believe that having personal and direct experience with a participatory policy or mechanism, in other words having close contact which will lead to personal experience for citizens regarding that policy or mechanism, will lead to a worse evaluation of the policy's or mechanism's performance. Also, Fung (2003) highlighted that the recurrence and iteration in contact, that is, whether it is a one-time event or a longer-term, ongoing endeavor, are two important qualities regarding a participatory process. These qualities may make the effect of the participatory policy more profound. As a result, many policymakers tend to establish policies to move from temporary to more stable, durable, and embedded forms of public contact (Nabatchi \& Amsler, 2014). Despite Font \& Navarro (2013), other scholars like Anderson (2010), suggest that individuals are empowered and motivated to participate when they believe that their involvement in and contact with the policy will be consequential, and therefore this belief may lead to a positive evaluation of the policy. However, Fernández-Martínez et al. (2020) warn those authority officials who make contact with citizens should be careful to not encourage citizens to set the bar of their expectation from the impact of the policy too high, otherwise this will lead to frustration from the policy by citizens. Moreover, Leach et al. (2002) stated that the outcomes of implementing policy plans and achieving tangible success could be a lengthy process and this affects the public perception of the policy's efficiency. Therefore, scholars like Font \& Navarro (2013) believe that citizens how are more familiar with the existing participatory plans and policies would provide lower evaluation scores. Because they know these policies and their plans are quite limited and their success achievement process will be quite long (Font \& Navarro, 2013). Whereas, policies with direct citizens' involvement, due to their participatory 
nature, are mainly looking for informing the public, that is, letting the public become familiar with issues, like future plans, changes that these plans could bring, resources to implement these plans (Nabatchi \& Amsler, 2014); and also trying to help citizens to acquire information on others' preferences and to take account of others' needs and interests (Papadopoulos \& Warin, 2007) besides their own preferences and interests to form a constructive participatory plan and clarify people's preferences concerning the plans regarding the participatory urban policies.

As some studies have discussed, participation is a two-way road, that is, if policymakers and their officials want people to refer to them, they need to actually listen to and care about what citizens have to say (Anderson, 2010). It is expected that the deliberation with citizens, or as Ulbig (2008) said "listening to the voice of people", to provide competent policymaking through reflection and, as far as possible, to consensual decisions (Papadopoulos \& Warin, 2007). This approach, that is, participating and deliberating with citizens, influences the participatory policies and increases the trust in these policies by citizens (Papadopoulos \& Warin, 2007; Ulbig, 2008). However, as Font et al. (2018) pointed out, if policymakers "cherry-pick" citizens' proposals in a participatory process then it will undermine significantly the public participation. As a result, this may lead to citizens' mistrust in the policy. Font et al. (2018) stated that two major reasons for this, first, extremely poorly designed and organized processes, and second, the role of local authority personnel who biased the results. Hence, as Fernández-Martínez et al. (2020) elaborated, the misadjusted design of participatory instruments and policies will lead to the citizens' fatigue of participation with policymakers and disconnection with the policy, and this, in turn, results in the distance between what is agreed with citizens and what is Implemented and consequently these become the major reasons for citizens' participatory frustration. Despite the risk of cherry-picking citizens' contributions and their participatory frustration, many scholars emphasize encouraging citizens in participatory urban processes. For this purpose, participatory policies are seeking for encouraging citizens to learn more about themselves, their community, or an issue like renovation, and possibly discovering innovative solutions for this issue in participation with urban officials (Nabatchi \& Amsler, 2014). This approach, as Scharpf (1999) stated, enhances the legitimacy of policy 'input', 'output', and more importantly 'throughput', that is, widespread beliefs about procedural fairness, owing to the involvement of actors with much local or sectoral knowledge. This in turn will increase the chances of policy acceptance (Papadopoulos \& Warin, 2007).

Studies have shown that increasing neighborhood amenities and facilities are potentially useful measures to promote the satisfaction of citizens (Wu, 2012). Therefore, policies that change the condition of the neighborhood toward a better one, at least from the citizens' point of view, increase their satisfaction from those policies. As a result, 
participatory policies are looking for increasing their public legitimacy by improving the quality of public life in the neighborhood (Papadopoulos \& Warin, 2007; Remesar 2020).

The findings of some studies suggested that direct public engagement processes can be designed with many general purposes and specific goals in the mind of policymakers (Nabatchi \& Amsler, 2014). Some policies and processes are designed to invoke individual or group action or change (Fung, 2003). Obtaining feedback, that is, understanding the public's views of a policy (Nabatchi \& Amsler, 2014), would be helpful to assess if the policy has worked as it meant to. In the case of current policy, that is NRSOs, the main goal of the policymakers is to invoke citizens to renovate UDAs and of course along with facilitating this process for them. The question is, how much this policy has reached this goal from the citizens' point of view.

Even though some studies assessed the performance of renovation policies in UDAs in Iran, few of them determined the residents' assessment of performance and mainly focused on other perspectives like physical improvement or, experts or policymakers point of views for assessment (Afzali \& Sharifi, 2016). Most importantly, the public opinion on the subject in combination with the factors which impact their opinion has been neglected so far. While, as it was discussed, residents of neighborhoods with UDAs are one of the major components for the success or failure of renovation policies. So, the influential factors on their assessment of these actions performance should be considered and used as a beacon for enhancing such practices in the future. It is conceivable that, if the role of citizens in assessment has been neglected, there is a danger that these assessments lead to biased results and even worse so, show false successes which can encourage urban authorities toward more wrong policies.

Based on these considerations, the citizens-based assessment of a renovation facilitating policy in urban deteriorated areas has been developed, which focused on factors involving residents rather than other variables.

The goal of this research is first to explore what factors could be extracted for the performance assessment of NRSO (as a renovation facilitating policy) by residents of UDAs. Second to find out whether these identified factors significantly impact the citizens of UDAs' point of view toward assessment of the NRSO performance.

For this purpose, we chose the NRSO of Fallah \& Yaftabad in region 17 of Tehran municipality as the case study and by application of questionnaires, 200 randomly chosen residents of UDAs in these two neighborhoods were face to face questioned. After a brief review of urban policies for UDAs from beginning till NRSO, by use of Exploratory Factor Analysis (EFA) and subsequently Ordinal Logistic Regression Analysis, the most important factors have been identified and explained. 


\section{A Brief Review of Urban Policies for UDAs from beginning till NRSOs}

Urban policies refer to national, and local government acts, that affect the spatial structure, administrative and economic institutions, and quality of life in urban areas through the provisions of development, direct and indirect interventions (Qadeer, 1996). Qadeer (1996) maintained the performance of urban policies is effective in life quality and urban sustainable life. Moreover, as Fernández-Martínez et al. (2020) pointed out that these policies have adopted the "participatory turn" as a way to address the growing disaffection and discontent among citizens. However, the question is, whether these participatory policies have been able to meet what they supposed to. Therefore, assessment of the performance of these policies is considered constructive for their success as well as for citizen's satisfaction and prosperity (Afzali \& Sharifi, 2016). As a result, renovation policies for UDAs are of no exception.

Tehran was a very small city when it became Iran's capital on 12 March 1786. (Naseri \& Safari, 2018). Since then, this city grows into a metropolis with 8.7 million inhabitants in 2016 (Statistical Yearbook of Tehran: Tehran City Statistics 2019, 2020) with around 32.7 square kilometers area. Urban management discrimination and incompetence in providing adequate facilities and helping in renovation of UDAs in deprived neighborhoods of Tehran, has caused a variety of malfunctions and problems, which alongside poverty and disparity create a vicious circle of humanitarian and socioeconomic crisis with the deterioration of urban areas; and this is why UDAs become a reality of our cities (Abbaszadegan, 2010; Akbarpour Saraskanroud et al., 2011; Tootoonchi \& Malekafzali, 2019). To break this vicious circle, it is required to intervene and repair the malfunctions in these UDAs (Abbaszadegan, 2010).

So far many policies have been practiced, from purely physical renovation without any communities' participation to participatory planning, utilizing social capital and socioeconomic empowerment of local communities (Abbaszadegan, 2010).

The first action to confront this problem was the establishment of the Tehran Renovation Organization (TRO) in 1967. After two years in 1969, 2000 hectares of Tehran urban areas were determined as deteriorated (Abbaszadegan, 2010). Since then many policies to eradicate these areas have been recommended and implemented by TRO, which not only did not solve the problem but also has resulted in the expansion of them (Rafieian \& Mohammadi Aydoghmish, 2016). A parallel organization to TRO, the Renovation Corporation of Tehran City (RCTC) was established in 1972, and yet another, the Renovation and Reconstruction Corporation of South of Tehran in 1977 were established (Abbaszadegan, 2010). Both corporations with no tangible outcomes. This inadvertency led to urban riots in the 1990s in several urban deteriorated areas of southern Tehran (Naseri \& Safari, 2018). Naseri \& Safari (2018) declared that this incident brought the so-called "problematic urban areas" to the authorities' spotlight 
again. At that time, urban authorities adopt a new policy, named aggregating small buildings, for the renovation of UDAs.

But again it made no improvement in the condition of these areas (Abbaszadegan, 2010). Therefore, in 1995 yet another new policy was developed, and let RCTC use financing- through shares, credits, and financial institutes like banks- for the renovation of these areas (Abbaszadegan, 2010). In 1996, new concepts such as empowerment and community participation, under the influences of global approaches and simultaneously with the establishment of the Urban Development and Revitalization Organization of Iran (UDRO) ${ }^{2}$ in the Ministry of Housing and Urban Development, have made their way into the domestic renovation literature (Naseri \& Safari, 2018). For its first actions, in the 2000s, UDRO began to identify the UDAs (Naseri \& Safari, 2018). From 2004 empowerment plans for UDAs were proposed; the main characteristic of them was their more participatory approach in relation to the past (Abbaszadegan, 2010).

In 2006 the first "participatory" plan for UDAs of Tehran was launched by the RCTC, but due to its decorative participation, this plan also ended as an unsuccessful experience with negative consequences in 2009 (Naseri \& Safari, 2018). In 2006, the Supreme Council of Urban Planning and Architecture of Iran ratified three criteria to identify UDAs (Azimi, 2016). These criteria were too rigid and unidimensional, that is physical, which have been criticized by many urban experts in many articles. In 2008 RCTC decided to launch the first local renovation offices, with the mission of facilitating the residents' participation in the renovation process, in the neighborhoods where having UDAs. However, it failed to continue because of the unstabilizing exogenous forces. Also, it created a lot of negative consequences and was put aside by the municipality in 2009 (Naseri \& Safari, 2018). From 2009 the RCTC role in renovation policies of Tehran had been faded and TRO took control. The TRO realized that the earlier master plans and interventions, because of inflexibility and lack of real communities' participation, did not have the ability to cope with the complicated problems of UDAs (Naseri \& Safari, 2018).

Circa 2010, the organization set up NRSOs $^{3}$ as a renovation facilitating policy and provided special incentives for people to provoke their participation. Shirvani (1985) stated facilitator approach uses participatory methods for both problem definition and generation of solution. Also Sanoff (2000) defined facilitation as a means of bringing people together to determine what they wish to do and helping them find ways to work together in deciding how to do it. it seems TRO has tried to run these renovation offices in the frame of Shirvani and Sanoff's definitions. But NRSOs is a

2.- This organization's title was changed to "The Parent Company of Urban Development and Revitalization of Iran", and again was changed to "Urban Regeneration Corporation of Iran".

3.- Formerly known as "Local Facilitating Offices" 
relatively novel experience in the renovation of the UDAs in Tehran and needs a lot of assessment. However, some scholars like Afzali \& Sharifi (2016) had this conviction that the recent policy has worked relatively well on the micro-scale. Table 1 presents the urban policies for UDAs from beginning till NRSOs.

\section{Urban Policies for UDAs from Beginning till NRSOs}

\begin{tabular}{|c|c|c|}
\hline Year & Policy & Result \\
\hline 1967 & Establishment of TRO & $\begin{array}{l}\text { Still one of the main } \\
\text { policymakers in the issue }\end{array}$ \\
\hline 1969 & $\begin{array}{l}2000 \text { hectares of Tehran urban areas was } \\
\text { determined as UDAs }\end{array}$ & Have changed few years after \\
\hline 1972 & $\begin{array}{l}\text { Establishment of RCTC to help TRO in } \\
\text { renovation polices }\end{array}$ & $\begin{array}{l}\text { Lost its power in } 2009 \text { due to } \\
\text { consecutive failures }\end{array}$ \\
\hline 1977 & $\begin{array}{l}\text { Establishment of Renovation and } \\
\text { Reconstruction Corporation of South of } \\
\text { Tehran }\end{array}$ & In had the same fate as RCTC \\
\hline 1990 & Aggregating small buildings policy & $\begin{array}{l}\text { Did not make any considerable } \\
\text { changes in UDAs; later it is used } \\
\text { as one of the NRSO missions }\end{array}$ \\
\hline 1995 & $\begin{array}{l}\text { Using financing from different sources for } \\
\text { renovation buy RCTC }\end{array}$ & It did not work as was expected \\
\hline 1996 & $\begin{array}{l}\text { Community empowerment and participation } \\
\text { conce pts entered to renovation literature } \\
\text { and establishment of the Urban Development } \\
\text { and Revitalization Organization of Iran (UDRO) }\end{array}$ & - \\
\hline 2000 & UDRO began to identify UDAS & $\begin{array}{l}\text { Since then UDRO introduce } \\
\text { many UDAs }\end{array}$ \\
\hline 2004 & Empowerment plans for UDAs & $\begin{array}{l}\text { It was not so succes sful due to its } \\
\text { top to down approach }\end{array}$ \\
\hline 2006 & $\begin{array}{l}\text { The first "participatory" plan for UDAs of } \\
\text { Tehran was launched by the RCTC } \\
\text { and resolutions of the Supreme Council of } \\
\text { Urban Pla nning and Architecture of Iran for } \\
\text { identifying UDAS }\end{array}$ & $\begin{array}{l}\text { Failed because its decorative } \\
\text { participation perspective } \\
\text { and these criteria still in use but } \\
\text { faced many critics }\end{array}$ \\
\hline 2008 & First local renovation offices lunched by RCTC & $\begin{array}{l}\text { Fail to continue after one year } \\
\text { because of the unstabilizing } \\
\text { exogenous forces }\end{array}$ \\
\hline $\begin{array}{l}\text { Since } \\
2010\end{array}$ & NRSOs as a renovation facilitating policy & $\begin{array}{l}\text { Some scholars assessed it as a } \\
\text { successful approach but it needs } \\
\text { to be assessed more }\end{array}$ \\
\hline
\end{tabular}

Source: Author elaboration based on different studies 
Saeed Najd Ataei Sarkarabad, Elahe Rezaei, Kyoumars Habibi:

Citizens-based Assessment of a Renovation Facilitating Policy in Urban Deteriorated Areas: An Ordinal Logistic Regression Model

Study Area
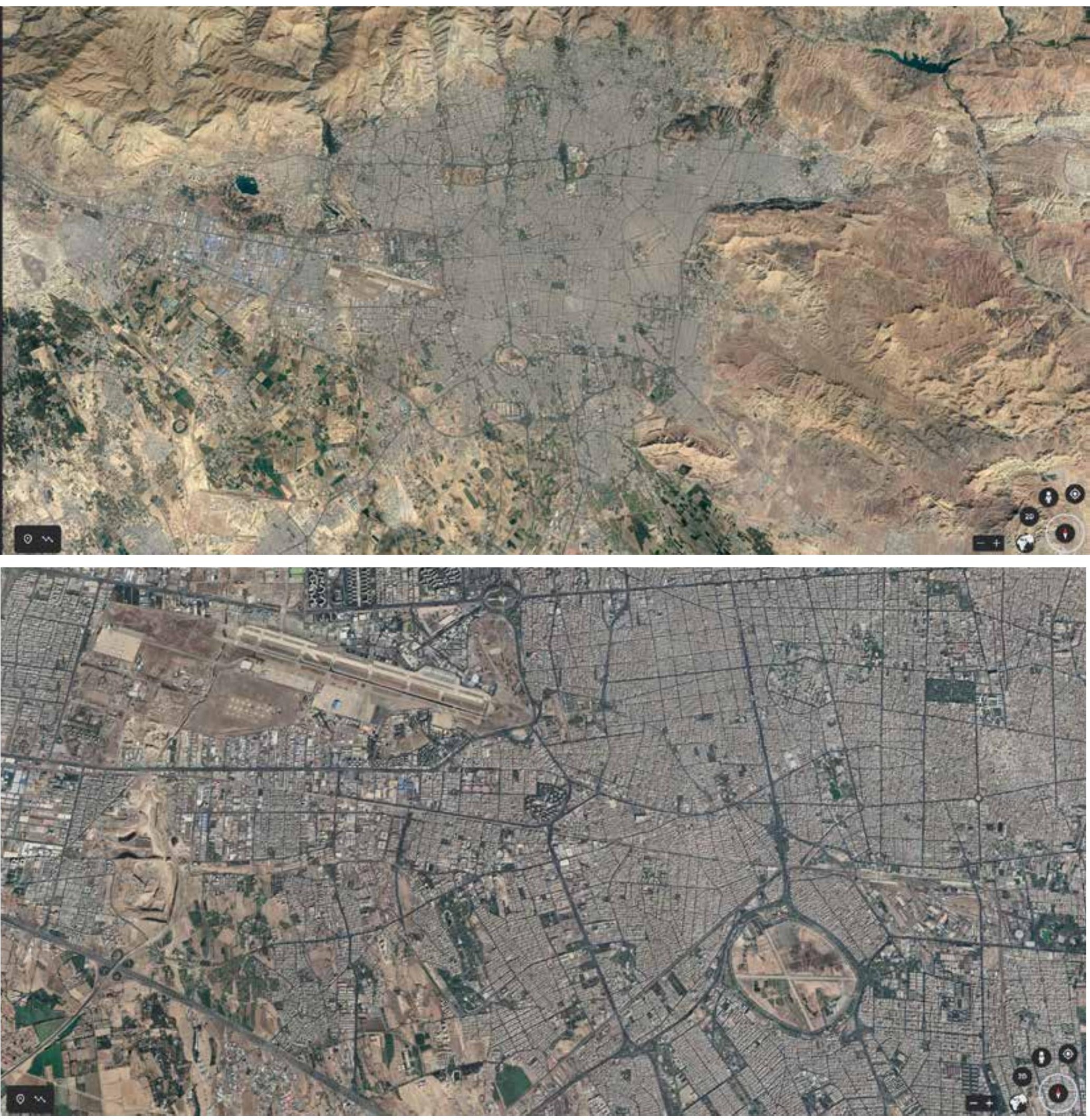

EDITOR'S NOTE: To facilitate the spatial understanding of the study area, we have introduced these Google Eartth images that position the study area in relation to the city of Tehran 

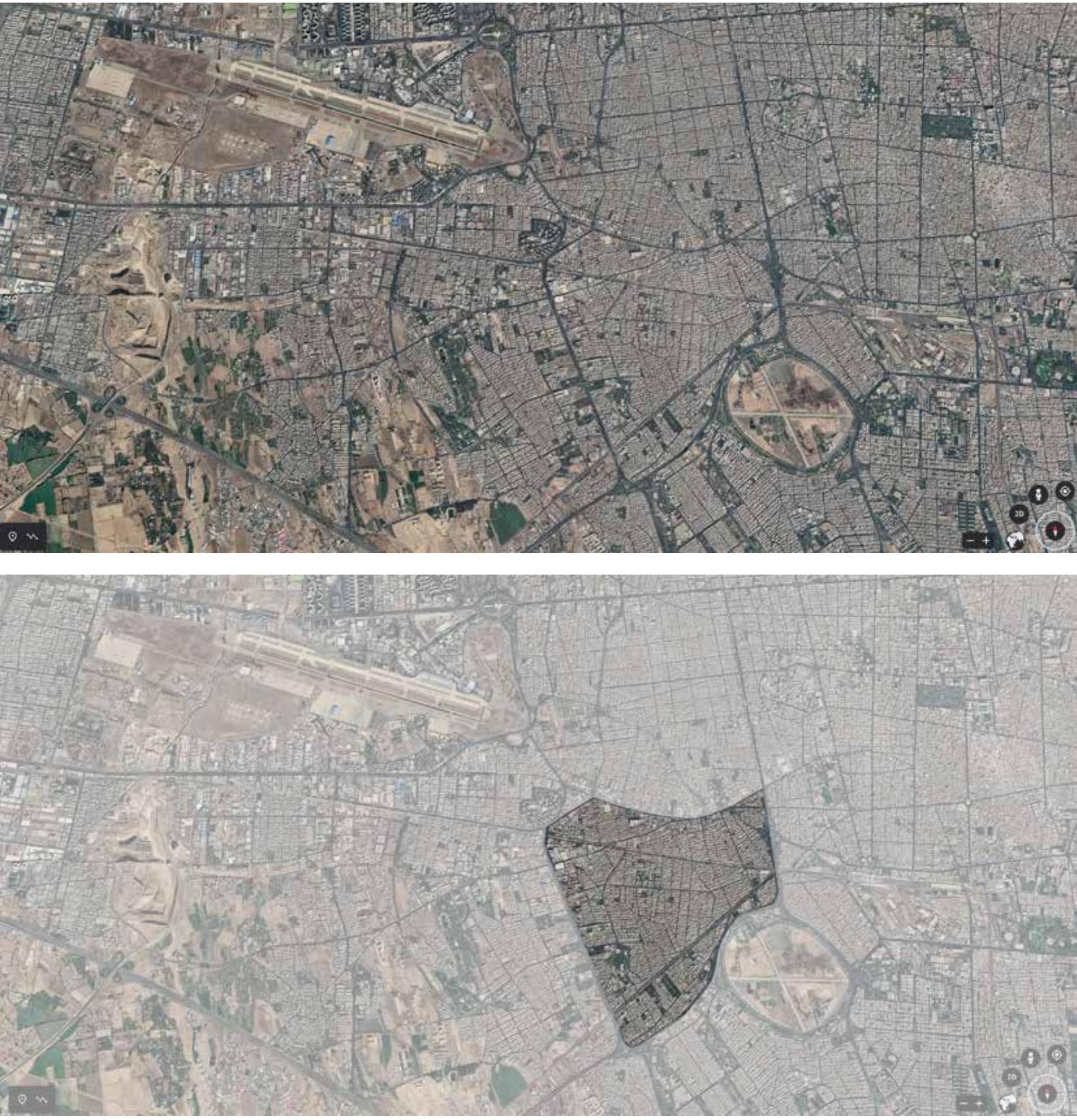

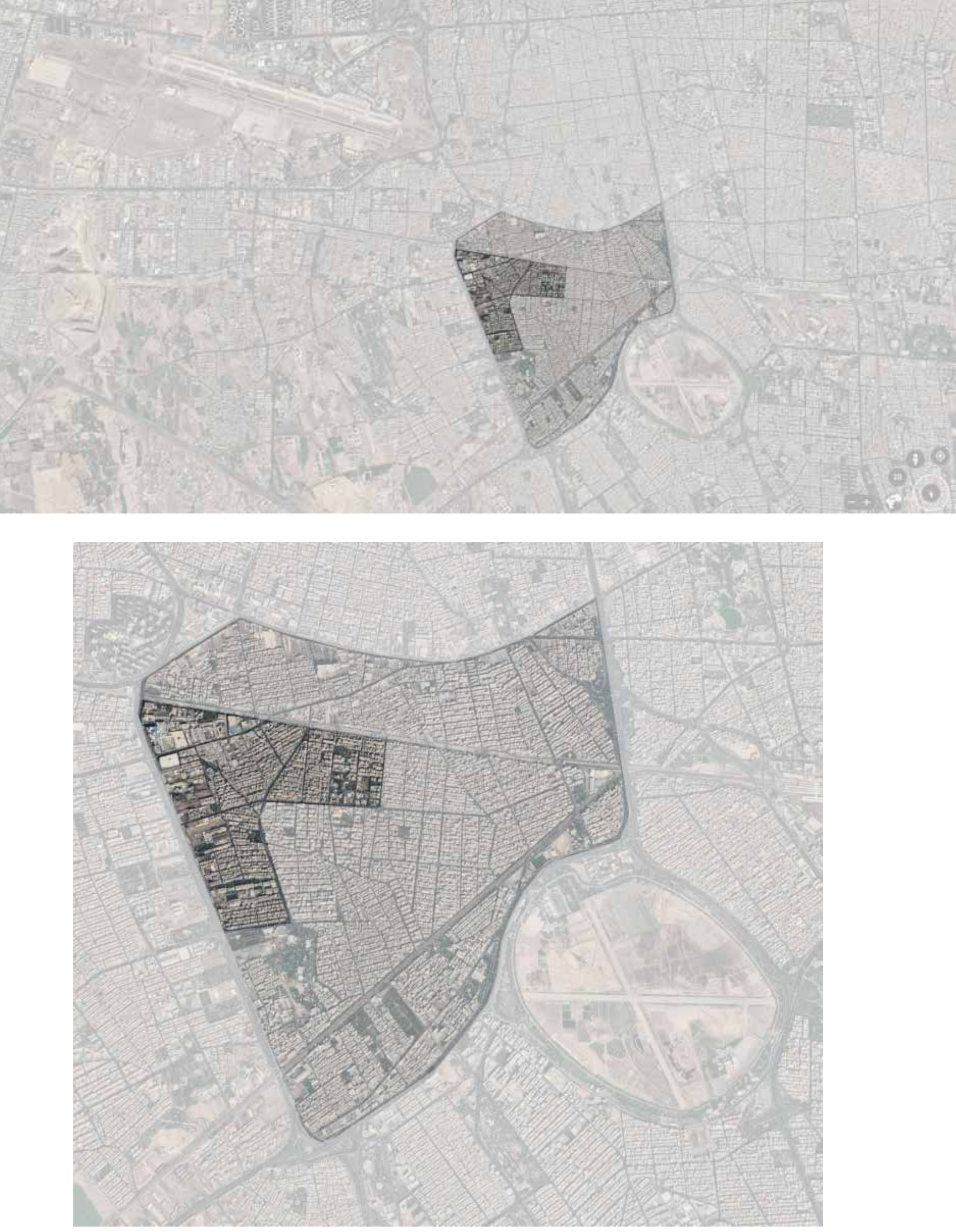
Tehran metropolis is the capital of Iran consists of 22 municipal districts. Fallah \& Yaftabad neighborhoods in district seventeen of Tehran municipal are two of 196 neighborhoods with the problem of UDAs in them. Actually, 2618 urban land plots out of 6357 total urban land plots of these two neighborhoods have the three criteria of UDAs, according to the resolutions of the Supreme Council of Urban Planning and Architecture of Iran in 2006. That is, $41.2 \%$ of neighborhoods 'total urban land plots and $46.9 \%$ of their residential's. 50 hectares out of 152.1 hectares of these two neighborhoods 'area is identified as UDAs, where 36.2 hectares of these UDAs is consist of residential land use.

These neighborhoods are located in the northwest of district 17. Even though these two neighborhoods are at adjacency the fanciest and luxurious furniture markets in Iran, that is Yaftabad Sofa Market, are one of the most deprived and poor neighbors in Tehran.

According to the Statistical Yearbook of Tehran (Statistical Yearbook of Tehran: Tehran City Statistics 2019, 2020) in 2016, 43901 people were living in our study area and this means a population density of 288.6 people per hectare. By considering very high population density, many buildings with lack of structural system, and Tehran being one of the most endangered cities in term of the earthquake (Amini Hosseini et al., 2014), make these neighborhoods one of the most vulnerable urban area, where their UDAs problem should be addressed as soon as possible.

These are some of the many reasons why Fallah \& Yaftabad are two target neighborhoods for the Renovation Facilitating Policy of TRO, which is the NRSO for these urban areas. Therefore, considering the goals of this research, the NRSO of Fallah \& Yaftabad is selected as a case study in this research. Figure 1 shows locations district 17 in Tehran, Fallah \& Yaftabad neighborhoods in district 17, UDAs in our study area, and finally our chosen urban land plots for the survey.

\section{Method}

\section{Participants}

A priori power analysis was conducted to estimate sample size with the aid of $\mathrm{G}^{*}$ power software ${ }^{4}$. Based on acceptable levels of effect size ( $\left.f 2=0.15\right)$, type I error $(\alpha=.05)$, and power ( $1-\beta=.95)$ (Dattalo, 2008); a sample size of 194 was estimated for our regression model, which in this research a 200 sample size (participants) were interviewed. The participants were being questioned as a part of the residents of urban deteriorated areas of two neighborhoods in region 17 of Tehran municipality.

4.- $G^{*}$ power software is a free specialized package for sample size estimation and power analysis. 

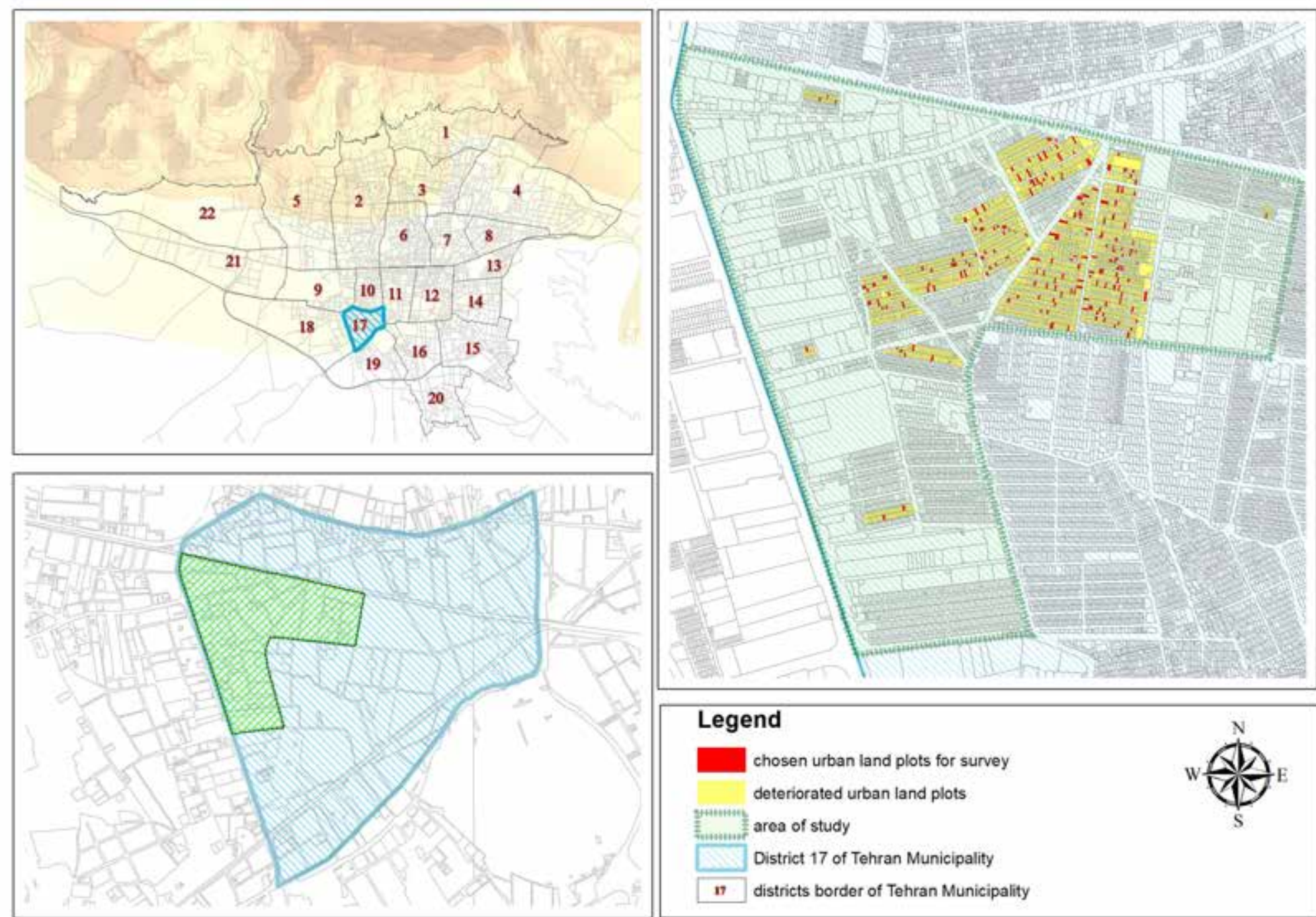

Fig 1.- Location of UDAs in Fallah \& Yaftabad and Districts 17 of Tehran. Source: Authors elaboration based on district 17 of Tehran municipality

Of these 82 were males and 118 were females. Their mean age was 41.6 years (SD = 14.53), with ages ranging from 18 to 76.

\section{Participants' Selection Process}

From where the under scrutiny policy had spatial effects over the study area; selecting samples which spatially randomly distributed was important to have unbiased results. As a result, a one-stage area sampling which is a common form of cluster sampling were employed (Kitchin \& Thrift, 2009). In this sampling, areas (deteriorated urban land plots) serve as the primary sampling units and, the population or total area under investigation is divided into mutually exclusive and exhaustive subareas using maps, and a random sample of subareas (chosen urban land plots) is selected (Kitchin \& Thrift, 2009). To implement this sampling, Subset Feature Selection (SFS) method was conducted in ArcGIS software. SFS method, which is an Equal Probability of Selection Method (EPSEM) (Kitchin \& Thrift, 2009), uses randomized sequential forward feature selection (Tracy et al., 2018) to create 200 random feature subsets. The two 

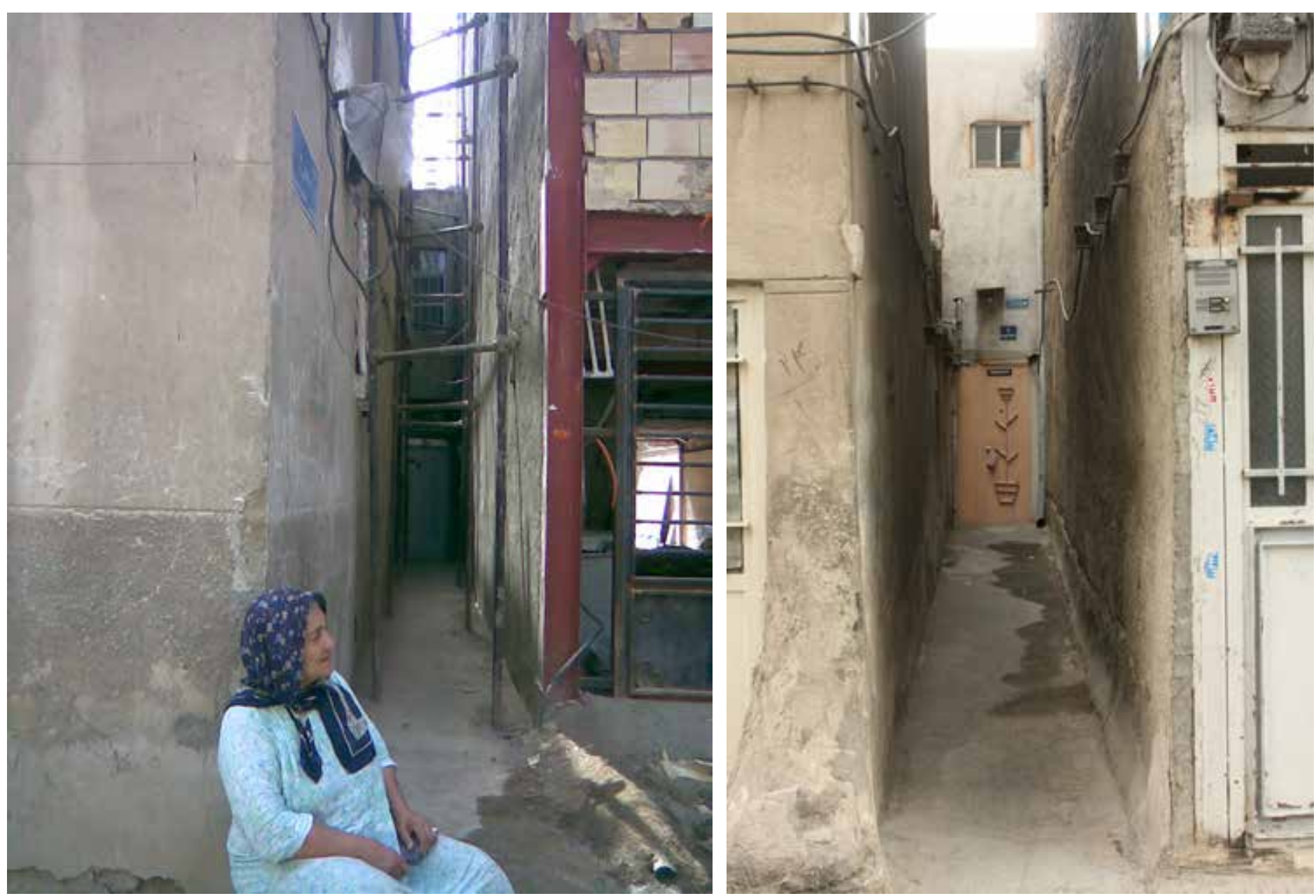

Old buildings inside UDAs. Source Authors

Criteria was used to select the samples were, first, households who are living in active residential urban plots in the UDAs of the study area, and second, accessibility to the participants, that is, if a household after two times returning was not accessible; the SFS method repeated for selecting alternative random participants till 200 interviews were meet. Consequently, urban land plots where were not residential, active, inside UDAs, and with accessible households, were excluded from the selection process. Figure 1 illustrates final chosen land plots where participants where residents of them.

\section{Materials}

To avoid ambiguity in questions, and to extract the main issues in the UDAs of Fallah \& Yaftabad, structured interviews by application of questionnaires were conducted. Respondents were selected randomly based on their urban land plot located in the study area and were interviewed by two interviewers over the course of one month in September of 2012. In order to have a random distribution of respondents in these neighborhoods and to undertake an unbiased analysis, the SFS method was conducted. To develop an appropriate template for the questionnaire, the review of the relevant contemporary materials from textbooks, journal articles, and conference 


\section{Variable Titles Inserted into SPSS and Their Related Question or Description}

\begin{tabular}{|c|c|}
\hline Variable title & Variable description or its related question \\
\hline House hold Income & How much is the household income per month in million IRR? \\
\hline Tehran Residency Duration & How long have you been living in Tehran? \\
\hline Willingness to Stay & $\begin{array}{l}\text { How much do you like to stay in the neighborhood, if the } \\
\text { current problems have been solved? }\end{array}$ \\
\hline $\begin{array}{l}\text { Neighborhood Residency } \\
\text { Duration }\end{array}$ & How long have you been living in this neighborhood? \\
\hline Real Dependency Burden & $\begin{array}{l}\text { the house hold real dependency burden (G hanbari et al., 2012; } \\
\text { Hasanzade et al., 2018) }\end{array}$ \\
\hline $\begin{array}{l}\text { Sense of Liking and } \\
\text { Belonging }\end{array}$ & $\begin{array}{l}\text { How much do you like your neighborhood and feel belonging } \\
\text { to it? }\end{array}$ \\
\hline Literacy Rate & The proportion of literate people in a household (Shah, 2013) \\
\hline Contact with NRSO & $\begin{array}{l}\text { How much contact have you ever had with the experts of the } \\
\text { NRSO? }\end{array}$ \\
\hline Acquainted with NRSO & How much are you acquainted with the NRSO? \\
\hline $\begin{array}{l}\text { NRSO Participation with } \\
\text { Citizens }\end{array}$ & $\begin{array}{l}\text { How much the NRSO experts have participated with citizens in } \\
\text { the neighborhood renovation process? }\end{array}$ \\
\hline $\begin{array}{l}\text { Neighborhood Change with } \\
\text { NRSO }\end{array}$ & $\begin{array}{l}\text { Have there been any changes in the quality of life (Khaef \& } \\
\text { Zebardast, 2016) in the neighborhood since the NRSO has } \\
\text { started to work? }\end{array}$ \\
\hline Acquainted with UDA Plans & $\begin{array}{l}\text { How much are you acquainted with the Urban Deteriorated } \\
\text { Areas (UDA) Plans for the Neighborhood? }\end{array}$ \\
\hline $\begin{array}{l}\text { NRSO Renovation } \\
\text { Participation Provocation }\end{array}$ & $\begin{array}{l}\text { How much do you find the NRSO activities helpful in provoking } \\
\text { participation for renovation among the neighborhood } \\
\text { citizens? }\end{array}$ \\
\hline $\begin{array}{l}\text { Renovation Improvement } \\
\text { with NRSO }\end{array}$ & $\begin{array}{l}\text { How much better the process of renovation in the } \\
\text { neighborhood has become since the NRSO has started to } \\
\text { work? }\end{array}$ \\
\hline
\end{tabular}

assessment on the NRSO performance and the indicators which could potentially affect this assessment by them based on this theoretical contextualization. Some of the provided questions were on a 5-point Likert scale and the others were on a continuous scale which was transformed to an ordinal scale. Table 2 demonstrates the variable titles inserted into SPSS and their related question or description.

Analyses

SPSS 26.0 was used to organize and clean the dataset, as well as being used to conduct the Exploratory Factor Analysis (EFA) and Ordinal Logistic Regression that appears within the results section. From where all the questionnaires were field by researchers through interviewing residents, there is no missing information. An EFA using Varimax 
rotation was performed to extracting latent variables. The orthogonal rotation was chosen as this keeps the factors independent in rotation (Field, 2009). Field (2009) believes Varimax allows for a general approach to EFA that generates factors containing a smaller number of more highly loaded variables onto each factor, making it more interpretable. The identified factors from EFA was used in Ordinal Logistic Regression (OLR) for finding out which factor among extracted factor has a significant impact on the citizens-based assessment of the NRSO in the study area.

An ArcMap 10.3 was used to present the maps and do calculations about spatial features and random selection of the target respondents by Subset Feature Selection. This selection method creates a random sequence used to create the subset features from the main feature. The features are selected by generating random values from a uniform $[0,1]$ distribution. So it provides a randomly selected urban land plot out of all UDAs' urban land plots for the survey from their residents.

\section{Results}

\section{Exploratory Factor Analysis (EFA)}

Exploratory factor analysis (EFA) is used to explore the underlying pattern of relationships among multiple observed variables (Baglin, 2014). The essential purpose of factor analysis is to describe the variation among many variables in terms of a few underlying but unobservable random variables called factors (Jobson, 1992). Exploratory factor analysis (EFA) methods are used extensively in the field of assessment and evaluation. EFA is useful for assessing the dimensionality of questionnaire scales that measure underlying latent variables (Baglin, 2014).

Shapiro-Wilk and Kolmogorov-Smirnov tests of normality found that indicators distribution significantly differs from a normal distribution $(p<.001)$. Therefore, a Principal Axis Factoring method-the suggested method for non-normal data (Costello \& Osborne, 2005) -of extraction with orthogonal rotation (Varimax) was conducted on the 14 variables in an attempt to explain the factors concerning neighborhood residents' assessment of NRSO Performance. As Kaiser (1970) suggests the KaiserMeyer-Olkin measure of sample adequacy is over $0.5(\mathrm{KMO}=.712)$, indicating a good adequate sample (Field, 2009). Bartlett's test of sphericity was significant $(\chi 2(91)=1121.788, p<.001)$, indicating that the 14 variables do not resemble an identity matrix and hold enough inter-item correlations for a sufficient EFA to have been conducted. Five components elicited eigenvalues that exceeded Kaiser's criterion of 1 , which in combination explained $71.005 \%$ of the variance. The scree plot showed inflection that would justify retaining components five (Figure 2). The Rotated Component Matrix presents the five-factor solution which explains variables 
Saeed Najd Ataei Sarkarabad, Elahe Rezaei, Kyoumars Habibi:

Citizens-based Assessment of a Renovation Facilitating Policy in Urban Deteriorated Areas: An Ordinal Logistic Regression Model
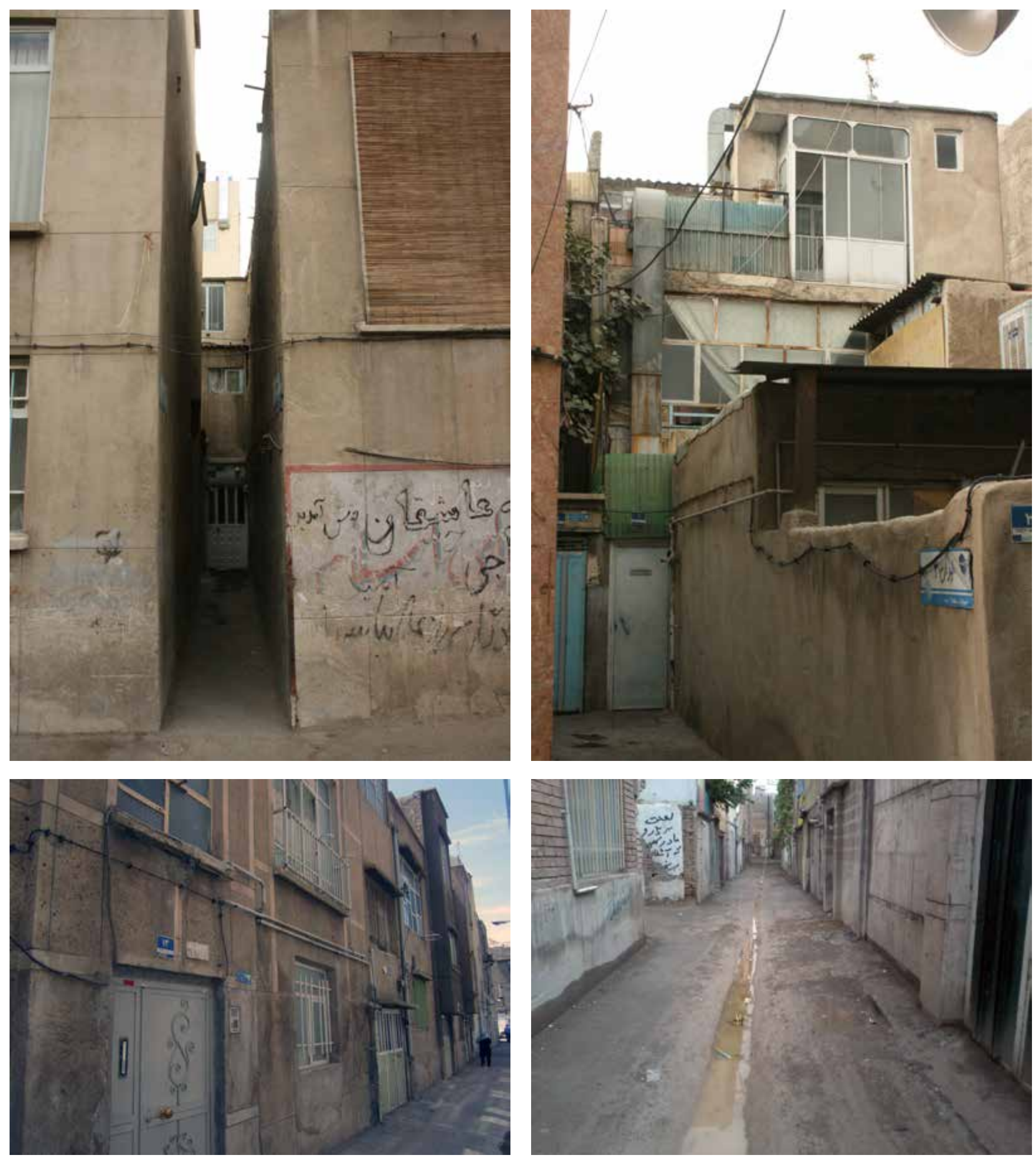

Old buildings inside UDAs. Source Authors 


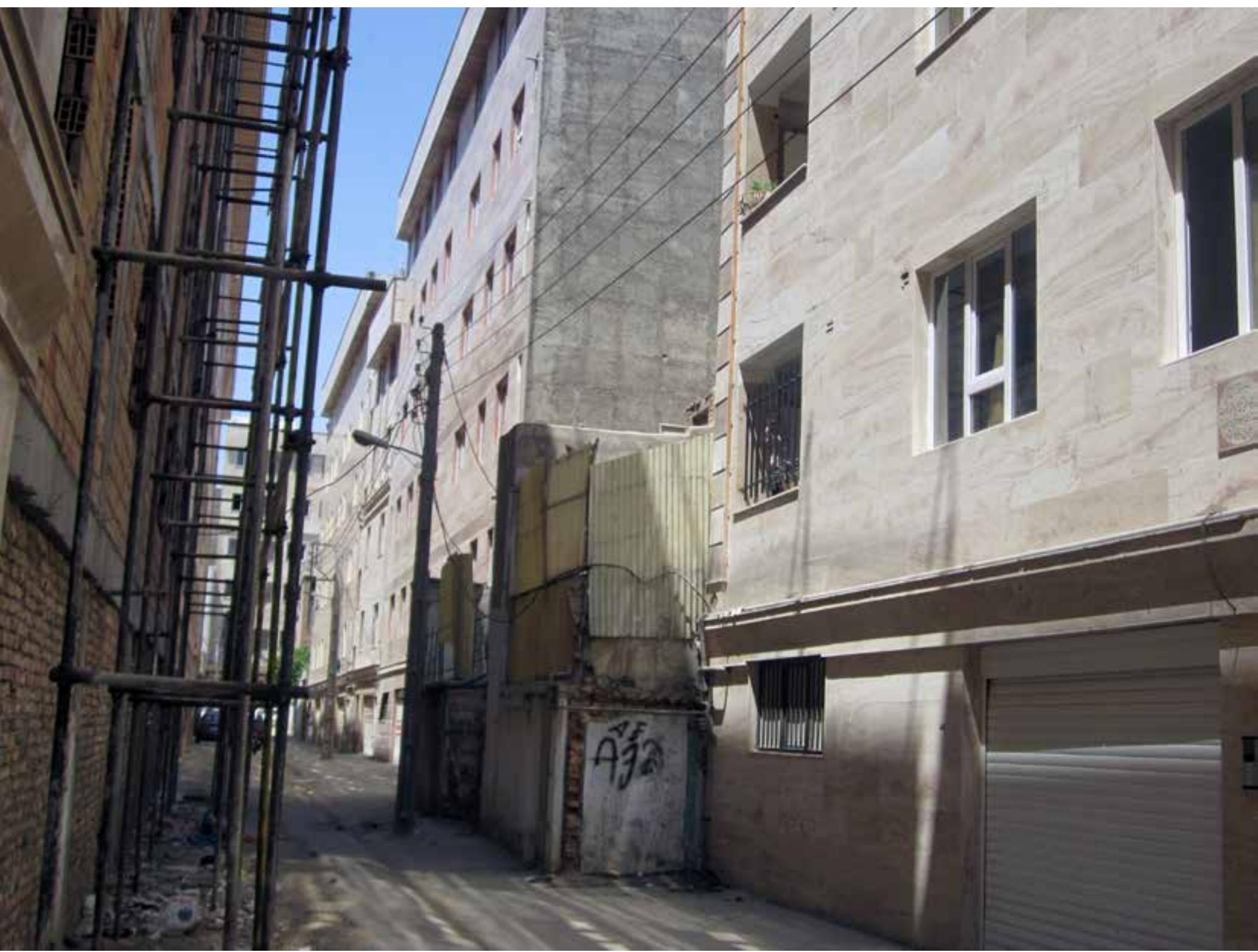

An old building among the renovated buildings. Source the authors

in relation to neighborhood citizens' assessment of NRSO Performance, with the factor 1 representing NRSO performance assessment (Renovation Improvement with NRSO, NRSO Participation with Citizens, Neighborhood Change with NRSO, NRSO Renovation" Participation Provocation, Contact with NRSO), factor 2 socioeconomic status of citizens (Household Income, Real Dependency Burden, Literacy Rate), factor 3 citizens' duration of residence (Tehran Residency Duration, Neighborhood Residency Duration), factor 4 citizens being acquainted with main components of renovation Policy in their neighborhood (Acquainted with NRSO, Acquainted with UDA Plans), and factor 5 citizens' sense of place to the neighborhood (Willingness to Stay, Sense of Liking and Belonging). The result of the EFA is shown in Table 3.

Also, for testing the internal consistency of our indicators a Cronbach's $\alpha$ test was conducted. The importance of reliability lies in the fact that it is a prerequisite for the validity of a test (Ho, 2006, p. 239). These 14 indicators have high reliability (Cronbach's $\alpha=.738$ ), which indicates that our EFA is internally consistent. 
Result of Explanatory Factor Analysis ( $\mathrm{N}=200)$

\begin{tabular}{|c|c|c|c|c|c|}
\hline & \multirow[b]{2}{*}{$\begin{array}{l}\text { NRSO } \\
\text { Performance }\end{array}$} & \multirow[b]{2}{*}{$\begin{array}{l}\text { Socioeconomic } \\
\text { Status }\end{array}$} & \multirow[b]{2}{*}{$\begin{array}{l}\text { Duration of } \\
\text { Residence }\end{array}$} & \multirow{2}{*}{$\begin{array}{l}\text { Acquainted } \\
\text { with } \\
\text { Main } \\
\text { Components of } \\
\text { Renovation } \\
\text { Policy }\end{array}$} & \multirow[b]{2}{*}{$\begin{array}{l}\text { Sense of } \\
\text { Place }\end{array}$} \\
\hline & & & & & \\
\hline $\begin{array}{l}\text { Renovation Improvement } \\
\text { with NRSO }\end{array}$ & .965 & .164 & .047 & .063 & .066 \\
\hline $\begin{array}{l}\text { NRSO Participation with } \\
\text { Citizens }\end{array}$ & .842 & .104 & .072 & .124 & .020 \\
\hline $\begin{array}{l}\text { Neighborhood Change with } \\
\text { NRSO }\end{array}$ & .837 & .181 & .055 & .077 & .053 \\
\hline $\begin{array}{l}\text { NRSO Renovation } \\
\text { Participation Provocation }\end{array}$ & .641 & -.017 & .068 & .045 & .292 \\
\hline Contact with NRSO & .502 & .049 & -.078 & .161 & -.055 \\
\hline Household Income & .001 & .816 & .112 & .123 & -.009 \\
\hline Real Dependency Burden & .099 & .678 & -.010 & .035 & -.030 \\
\hline Literacy Rate & .272 & .510 & -.018 & -.103 & -.113 \\
\hline Tehran Residency Duration & -.027 & .043 & .866 & .029 & .037 \\
\hline $\begin{array}{l}\text { Neighborhood Residency } \\
\text { Duration }\end{array}$ & .074 & .024 & .753 & .129 & .012 \\
\hline Acquainted with NRSO & .216 & .017 & -.032 & .965 & -.014 \\
\hline Acquainted with UDA Plans & .078 & .029 & .158 & .311 & .042 \\
\hline Willingness to Stay & .010 & -.027 & -.076 & .123 & .724 \\
\hline $\begin{array}{l}\text { Sense of Liking and } \\
\text { Belonging }\end{array}$ & .106 & -.071 & .100 & -.063 & .509 \\
\hline$\%$ Variance Explained & 27.507 & 13.134 & 12.495 & 9.174 & 8.695 \\
\hline Eigenvalue & 3.851 & 1.839 & 1.749 & 1.284 & 1.217 \\
\hline
\end{tabular}

$\mathrm{KMO}=.712$, Bartlett's ?2 = 1121.788, p<.001

Extraction Method: Principal Axis Factoring.

Rotation Method: Varimax with Kaiser Normalization.

a. Rotation converged in 5 iterations.

Table 3 


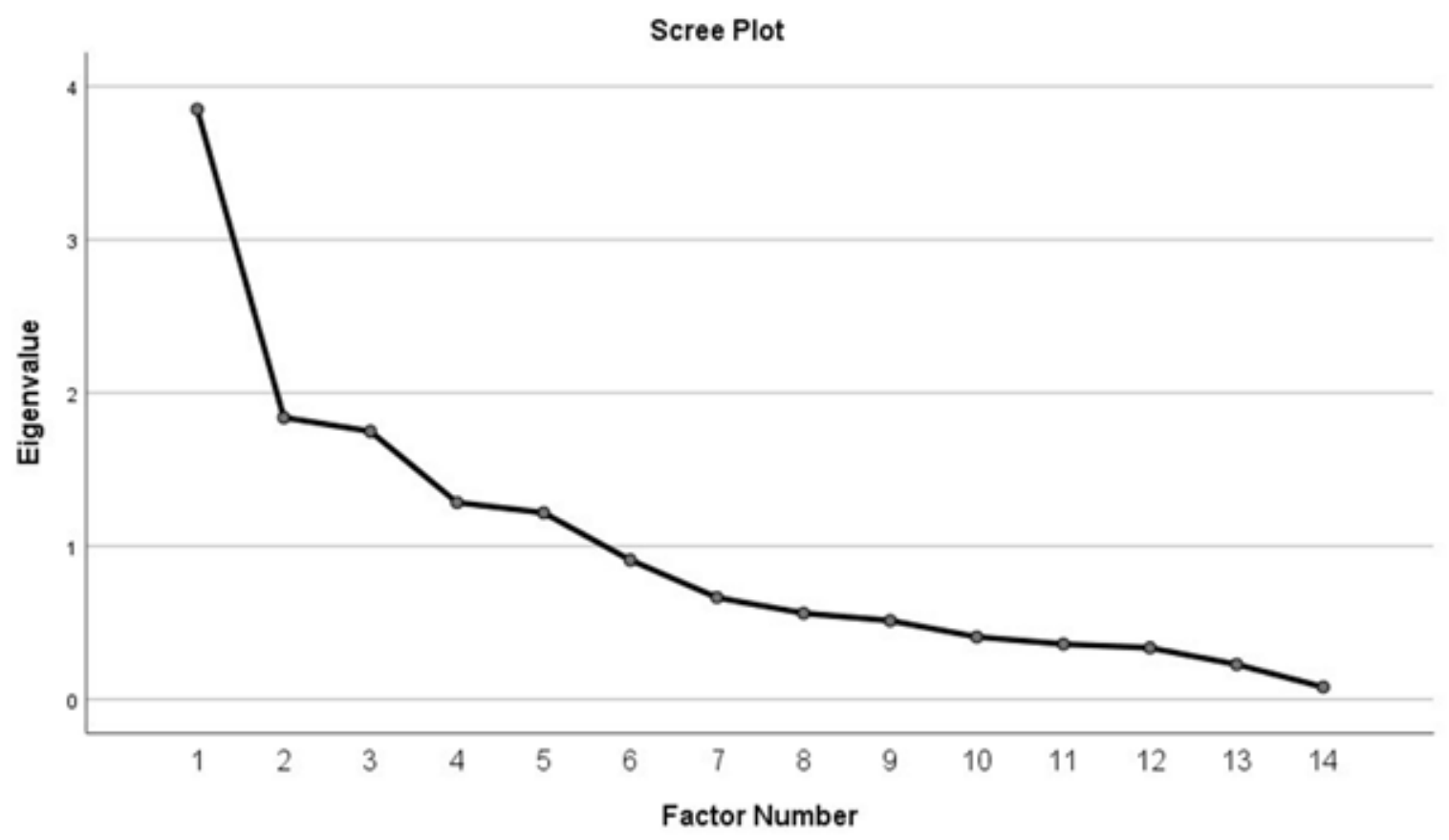

Fig. 2 Scree Plot Determines Five Factors to Retain in the EFA
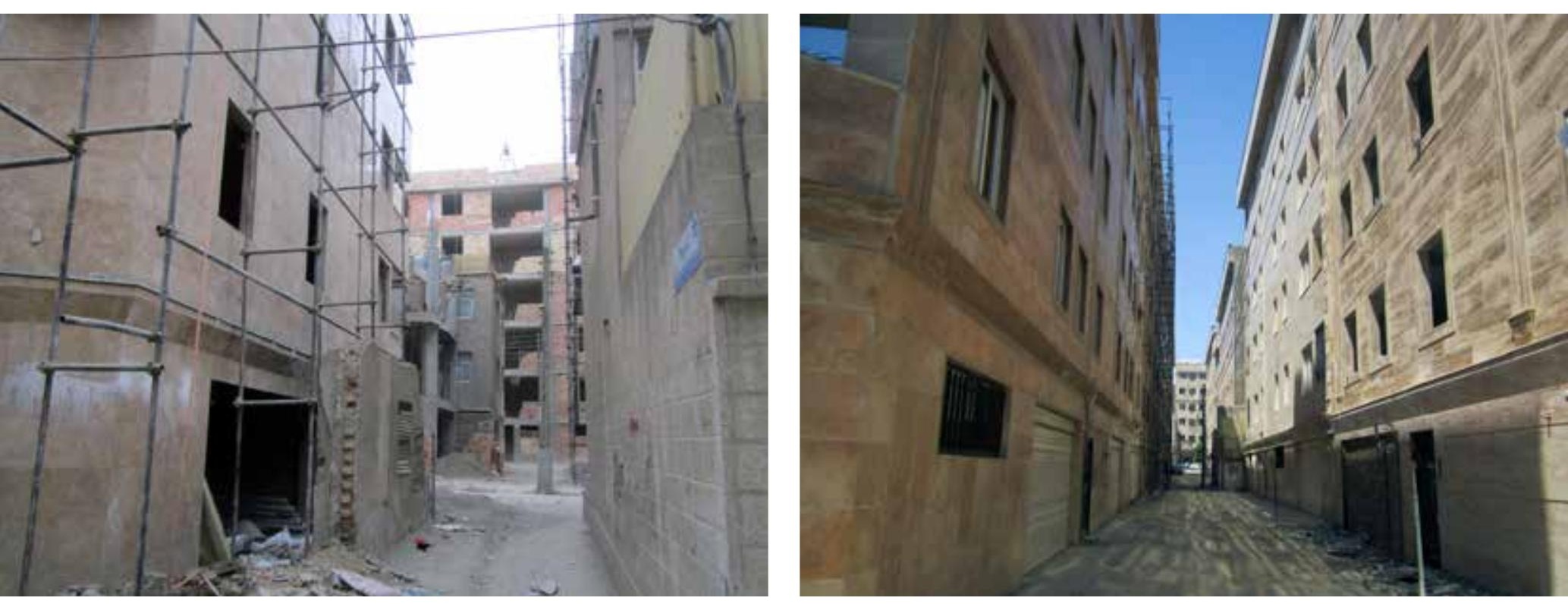

Renovated buildings under the effect of NRSO. Source the authors

\section{Ordinal Logistic Regression (OLR)}

Ordinal Logistic Regression (OLR) is a special type of multinomial regression, which is geared to response variables with ordinal effect. The OLR is commonly used to test or model the association between the ordinal target variable and a number of potential predicting variables, with each association estimated in terms of an odds ratio (OR) (Warner, 2008).

An ordinal logistic regression analysis shows that there is a significant influence (Frank E. Harrell, 2015) of Socioeconomic Status, Sense of Place, and Acquainted with Main 
Components of Renovation Policy on neighborhood citizens' assessment of NRSO Performance $(\chi 2(4)=21.965, p<.001)$. The model explains 11.1 of variance in citizens' assessment of NRSO (Nagelkerke R2). The results show that for every unit increase in Socioeconomic Status of the neighborhood citizens $(B=.410$, Wald $\chi 2(1)=8.064$, $\mathrm{p}<.01$ ), being Acquainted with Main Components of Renovation Policy ( $B=.469$, Wald $\chi 2(1)=7.976, p<.01)$, and Sense of Place of residents to the neighborhood $(B=.359$, Wald $\chi 2(1)=6.068, p<.05)$, the odds for positively assessing the NRSO performance by citizens is 1.507 times, 1.599 times, and 1.432 times. However, Duration of Residence did not significantly predict neighborhood citizens' assessment of NRSO Performance $(B=.13$, Wald $\chi 2(1)=.006, p>.05)$. The result of the OLR is shown in Table 4 .

\section{Result of Ordinal Logistic Regression Analysis}

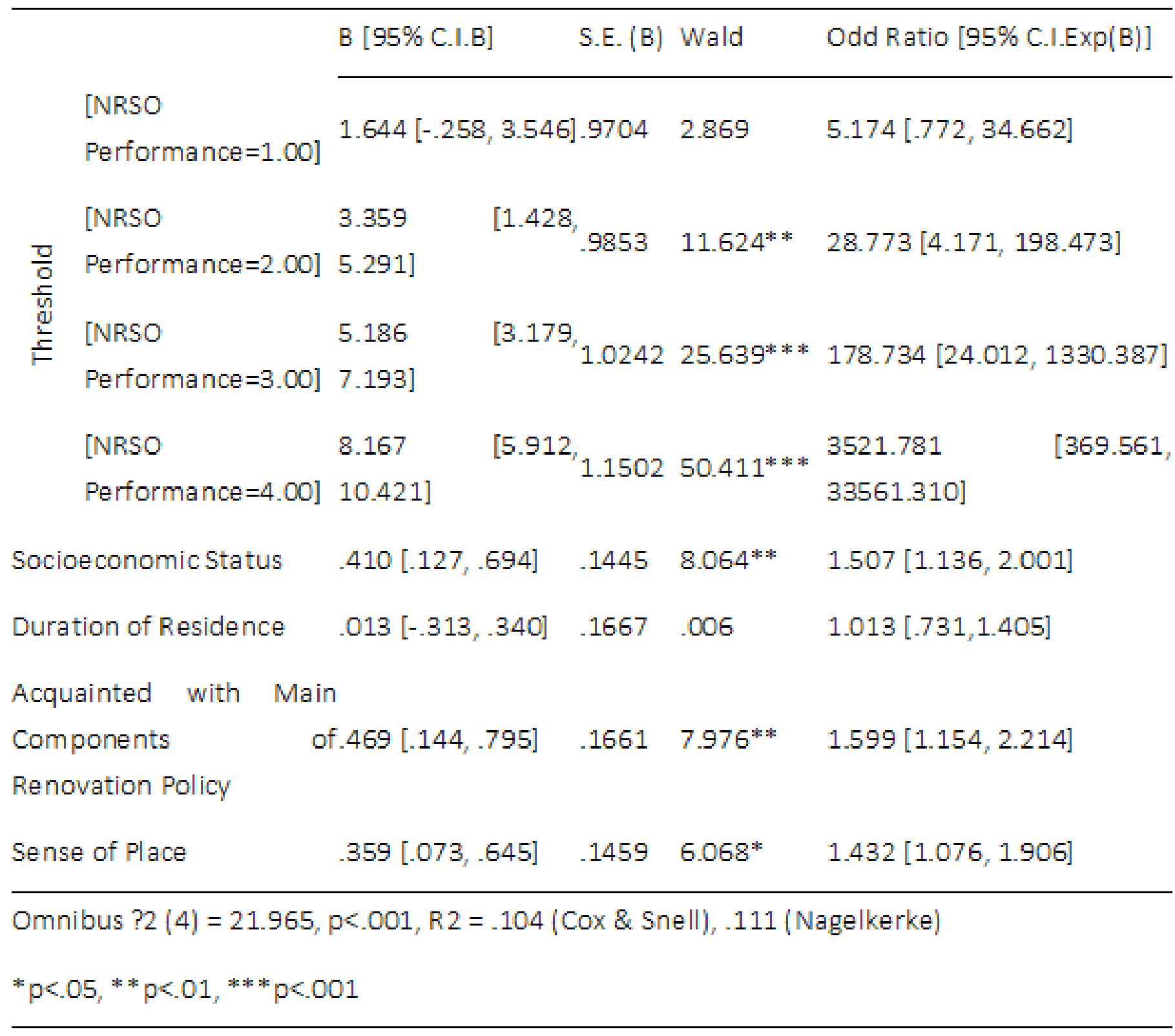




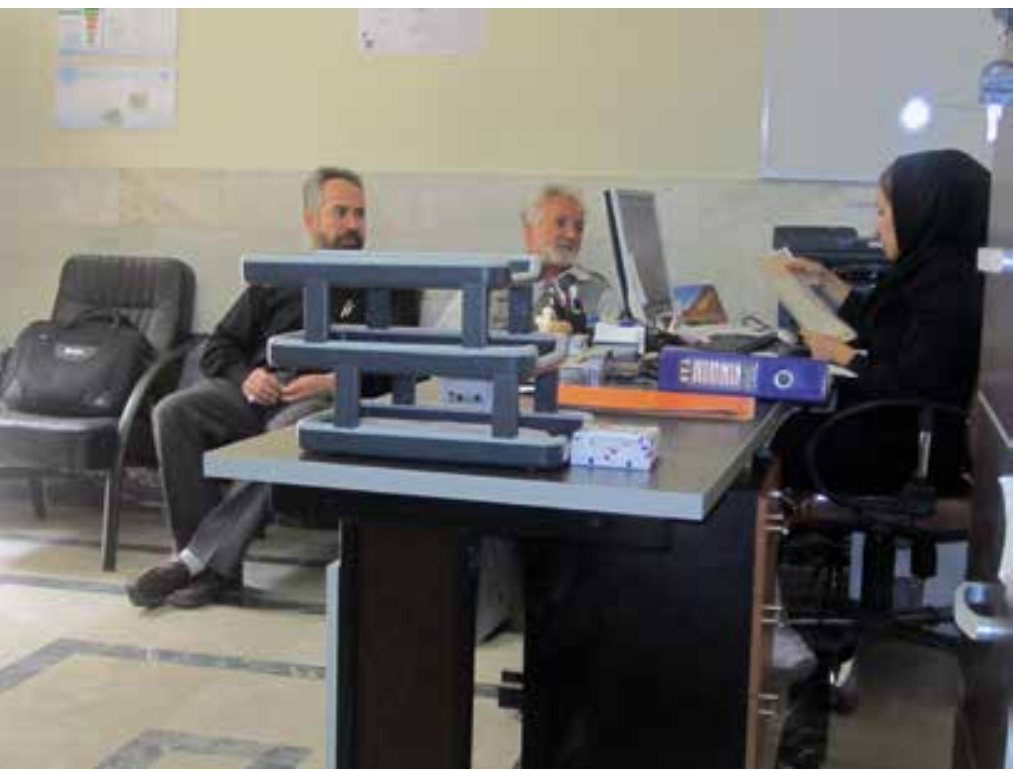

Citizens refer to NRSO for consulting with the experts about renovating their old building. Source the authors

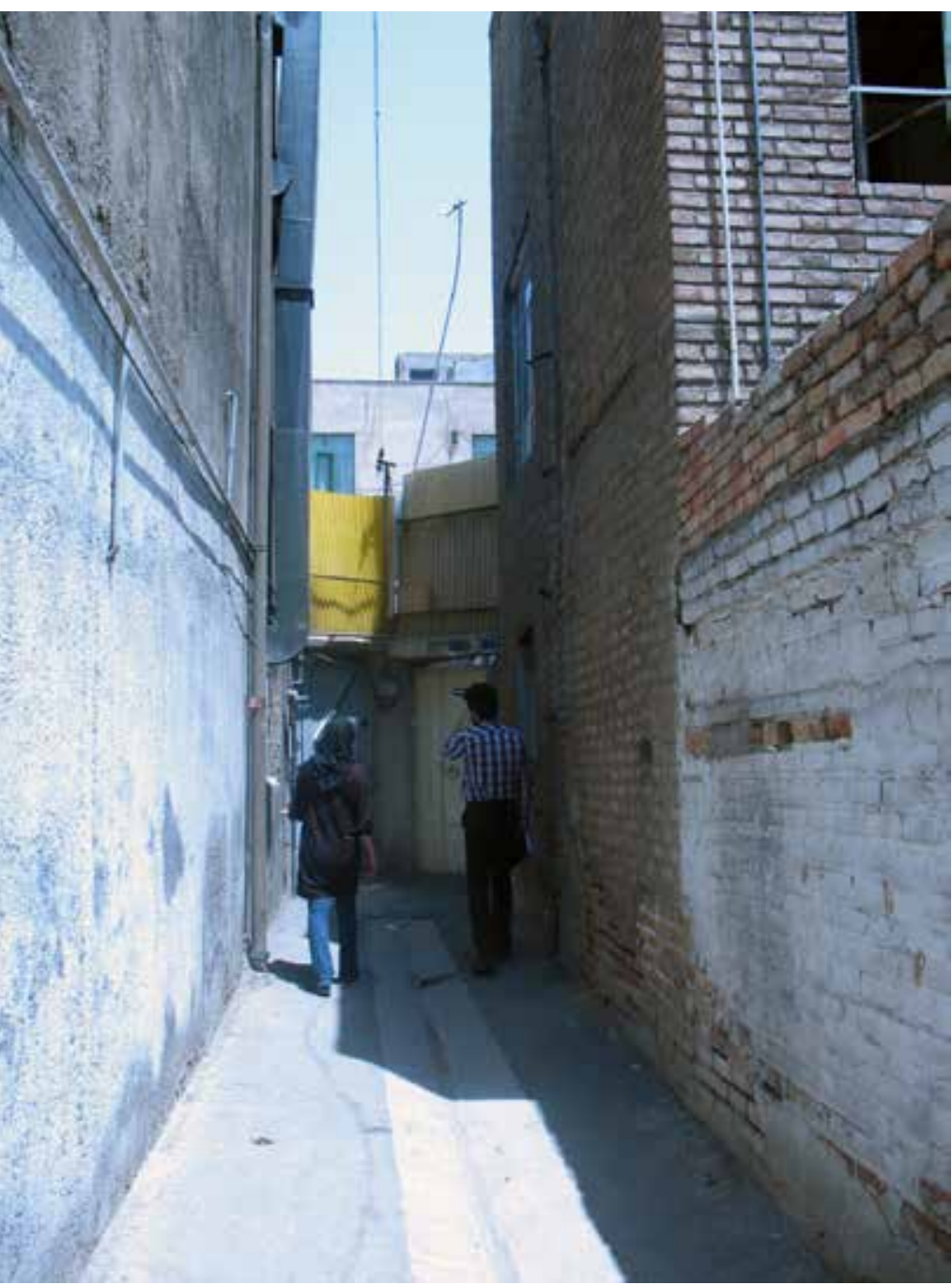

Interviewers referring to one of the chosen urban land plots for interview.Source the authors

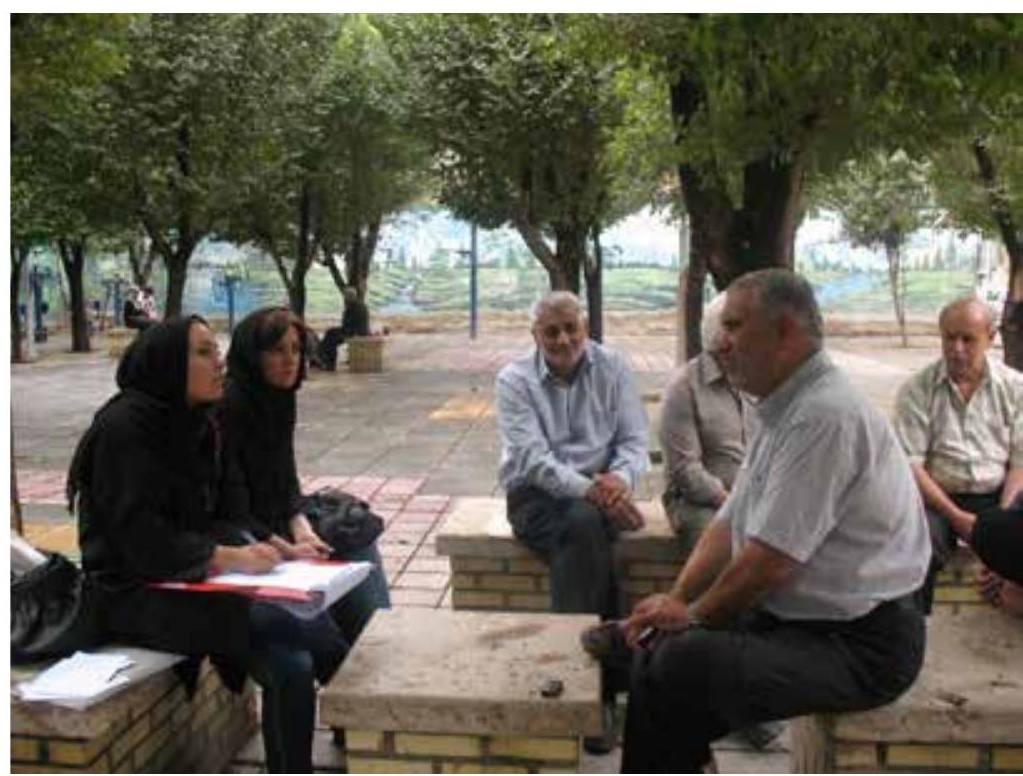

One of the focus groups of the expert(s) of NRSO with citizens of UDAs in a local park. Source the authors

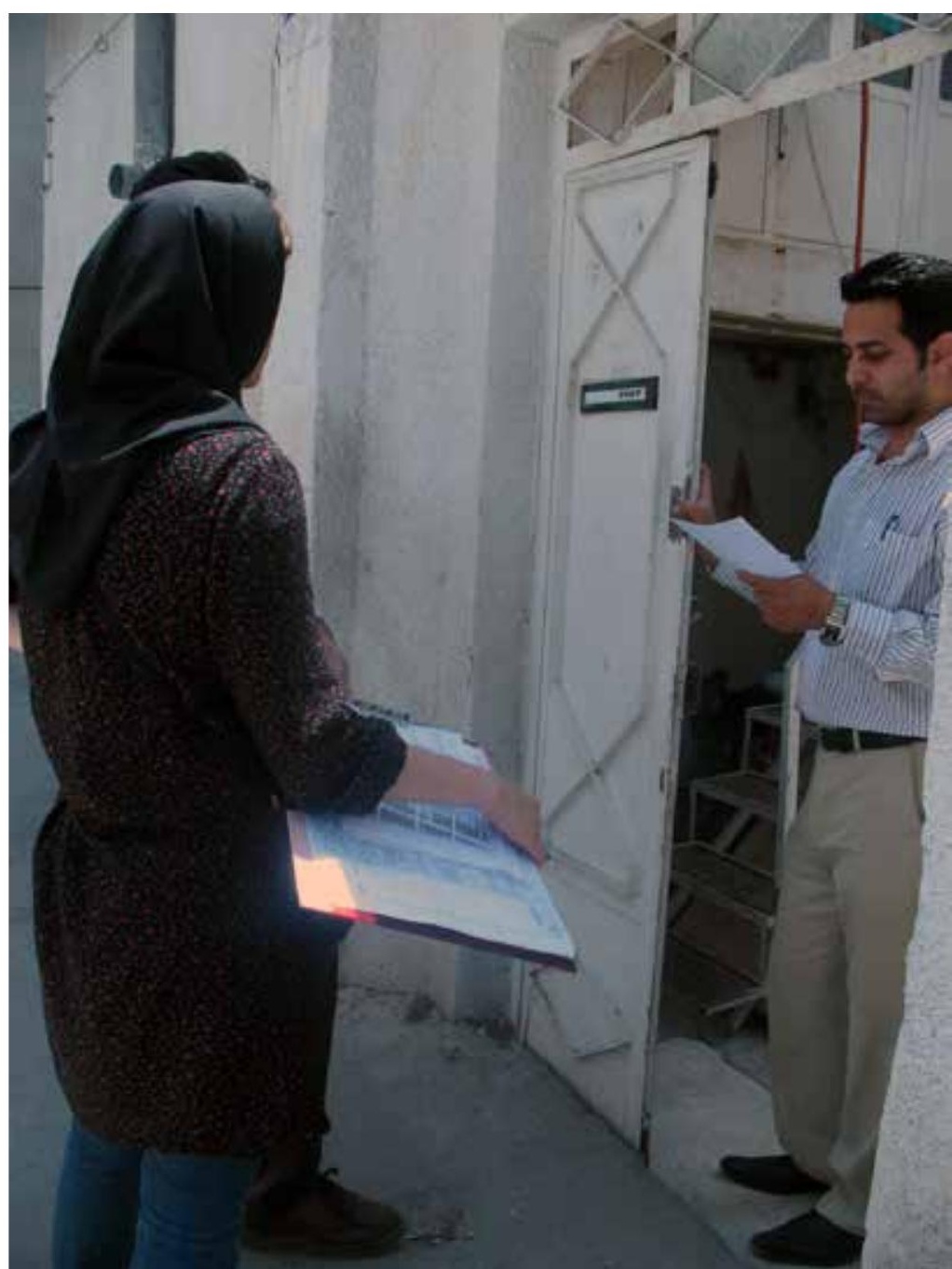

Interviewers talking with one of the UDAs' residents.Source the authors 


\section{Discussion and conclusion}

In the present article, we investigated what factors could be extracted for the performance assessment of NRSO (as a renovation facilitating policy) by residents in UDAs. Also, our study addressed the question of whether these identified factors significantly impact the citizens of UDAs' point of view toward assessment of the NRSO performance. For this, we interviewed 200 residents of UDAS of Fallah and Yaftabad neighborhoods in district 17 of Tehran municipality. We have found, 14 indicators depicted five factors; out of which, four influential (Socioeconomic Status, Duration of Residence, Acquainted with Main Components of Renovation Policy, Sense of Place) that could impact the target factor, NRSO Performance, was extracted through EFA. Moreover, three factors out of four predictor factors showed a significant positive impact on the assessment of NRSO performance by citizens.

Our result gave us four possible explanations as follows. Firstly, among four predicting factors, being acquainted with the main components of renovation policy (NRSO and UDA Plans) has the most impact on NRSO performance assessment in comparison to other factors. This clearly illustrates that if NRSOs what to have better performance in association with people, they need to be more informative about themselves and engage residents more in actions and the plans related to UDAs. Secondly, another factor that significantly influenced the people's positive assessment of NRSO performance is residents' SES (Household Income, Real Dependency Burden, Literacy Rate). This exclusively points towards the empowerment duty of NRSOs. Consequently, a vivid picture of this outcome is, an economically and socially empowered community is a key factor for the success of NRSOs. Thirdly, the Sense of Place (Willingness to Stay, Sense of Liking and Belonging) is another significant factor that is influential on NRSOs performance. As Shamai (1991) suggested, the sense of place consists of belonging, attachment, and commitment to a place or part of it. However, what creates a true sense of place is a complex task, because it varies from person to person (Shamai, 1991). But what is conceivable among all these ambiguities is, if the more people involve with their neighborhood improvement, the more they feel attached to it. Also, as is shown in the brief review of renovation policies, one predominant factor for malfunctioning of these policies, in many scholars' view, was lack of participation and top to down approach. Hence, this perspective drew the path for NRSOs toward effective participation. Base on David Wilcox (1994), facilitators not only should consulate with citizens in urban issues that affecting them and providing opportunities for joint decision making, but also they have to form a partnership to carry out the joint decision and supporting independent community interests. Finally, we learned, NRSOs performance assessment, has nothing to do with the duration of residence of citizens. Even though findings in the literature review highlighted the association between duration of residence and participation (Kang \& Kwak, 2003; Kasarda, J. D.; 


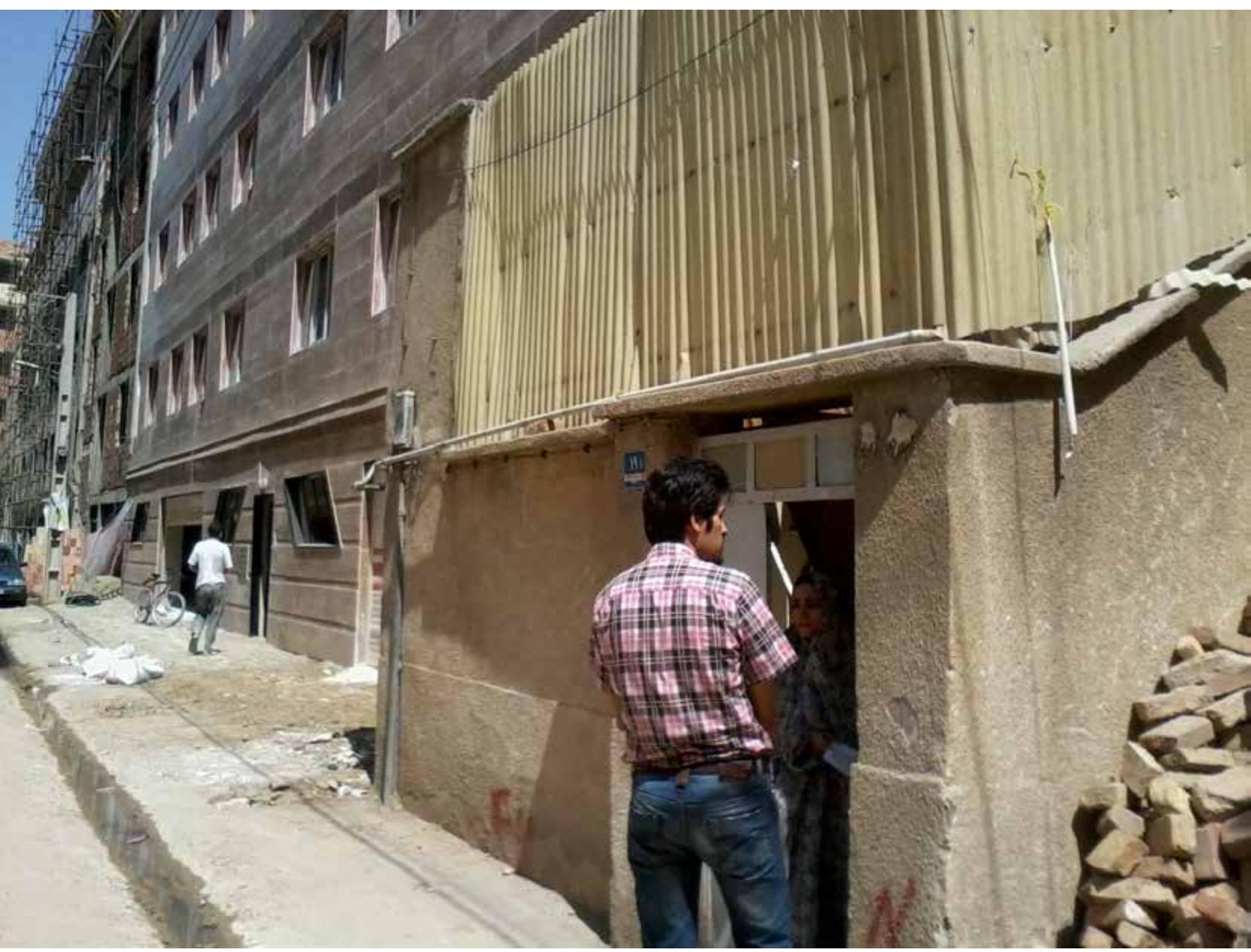

Interviewers talking with one of the UDAs' residents. Source the authors

Janowitz, 1974; Wu, 2012), our finding revealed that this may be the case for the participation of citizens, but not for their assessment of an urban participatory policy.

Our research continued Abbaszadegan's (2010) research timeline, which mainly focused on the policies before 2010; and assessed the renovation policy which has been run since 2010, that is NRSOs. Furthermore, our assessment identified more dimensions from assessment just by participation in its different levels. Contrary to many research, like Afzali \& Sharifi's (2016) investigation, which mainly focused on the product for assessment, our research improved the previous study and tried to find latent variables of these assessments to draw a bigger picture for future intervention policies in UDAs.

Recent renovation policies' assessment literature, especially in Iran, is widely focused on product assessment, that is renovation improvement in urban areas. But what keeps a body alive is the soul; thus policymakers should address the soul (residents), besides 
Saeed Najd Ataei Sarkarabad, Elahe Rezaei, Kyoumars Habibi:

Citizens-based Assessment of a Renovation Facilitating Policy in Urban Deteriorated Areas: An Ordinal Logistic Regression Model

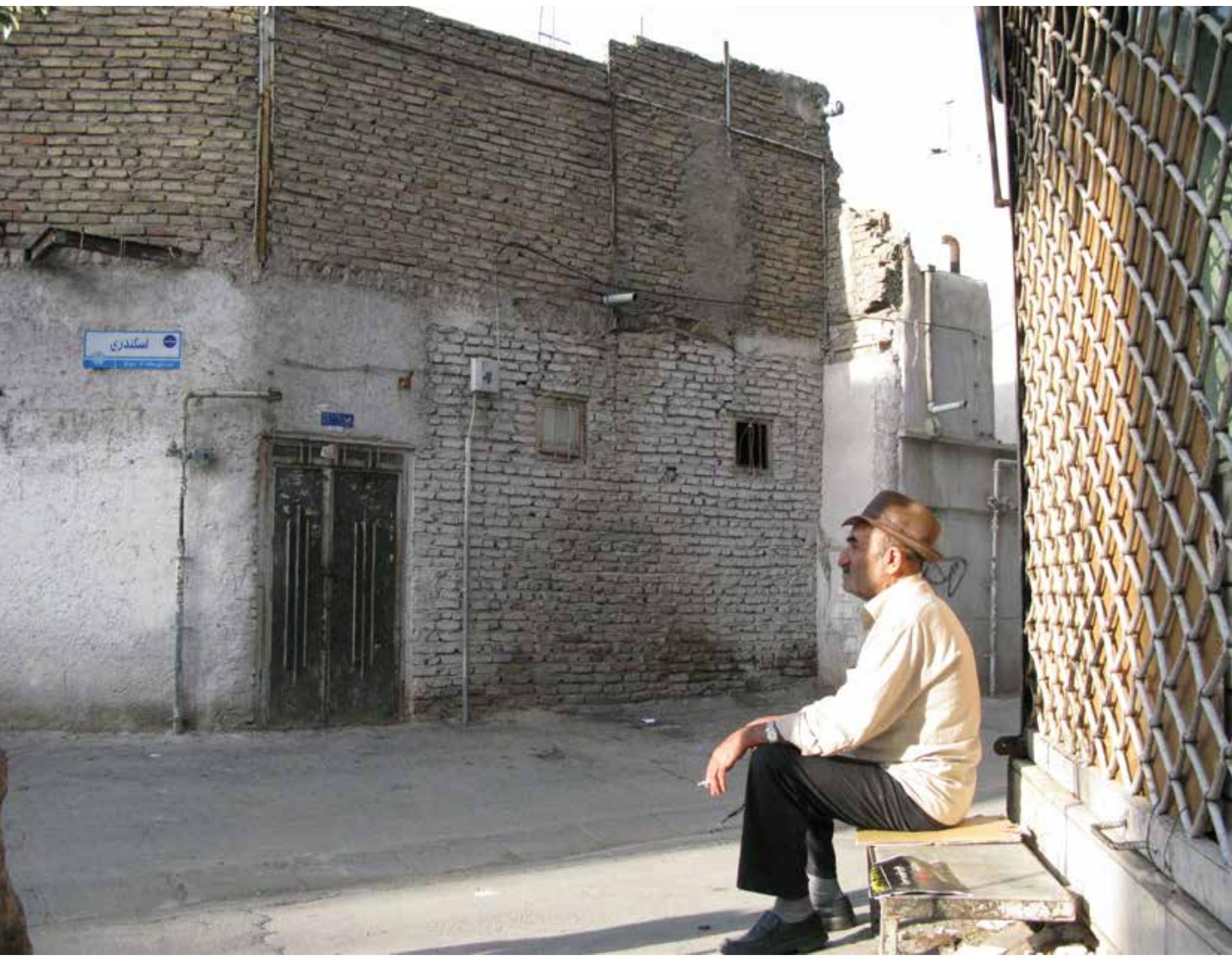

Old buildings inside UDAs. Source Authors

the body, through respecting them by engaging them with what is affecting their lives. They have to build residents' self-esteem by empowering them economically and socially, and finally make them the partners and even more so, decision-makers of their own living environments (Remesar, Antoni, 2020). Then the renovation process will move toward an uplifting stream. This is what our survey reflected from the citizen's perspective. Hence, our research offered a new approach for the assessment of urban policies performance, and that is finding out underlying factors impacting citizens' views and try to analyze and deal with them first to achieve brighter outcomes.

Although there was little prior research in this particular aspect, we tried to find the indicators based on our own experience and some literature. So our ordinal logistic model could explain only $11.1 \%$ of the variance for NRSOs performance assessment. However, the Omnibus test showed that the predictor factors significantly explain the variation from the baseline model and our model is robust. Our study area was 
limited due to the lack of time and financial resources. More neighborhoods needed to be investigated to have a more extensive comprehension of these issues. However, subset feature selection has been applied to have a spatially random distribution in our study area to gain more diversity in the scope of our two neighborhoods. Despite the non-extensive study area, our results are significant.

We investigated what underlying factors could be influential in the NRSOs performance assessment by residents involving in UDAs; and whether these factors could significantly predict the performance assessment of NRSOs by residents of UDAs. Our findings showed, four main factors can be identified from our indicators and it was confirmed that 3 of these factors significantly predict the assessment of NRSOs performance by residents of UDAs. This offers a novel perspective on urban policies assessment, and that is, citizens-based assessment for discovering influential latent factors which are the significant role-players for the performance of urban policies. Further researches through more assessments that follow this approach should be developed to find more latent factors in this regard or even retest current extracted factors as a Confirmatory Factor Analysis (CFA) in different study areas.

\section{References}

ABBASZADEGAN, M. (2010). Community based participatory planning as a renovation policy. International Journal of Sustainable Development, 10(01), 69-74.

ABDOLLAH, A., FARD, Z., ANDALIB, A., MAJEDI, H., \& BAZRGAR, M. (2014). Description of Public Participation Components in Rehabilitation and Renovation of the Deteriorated Urban Area : A Case study of Old District ,. 3(9), 119-127.

AFZALI, R., \& SHARIFI, A. (2016). Performance assessment of urban renewal organization to environmental improvement ( Case study: Worn texture areas of Tehran ). Geographical Urban Planning Research, 4(3), 14-17.

AKBARPOUR SARASKANROUD, M., POURAHMAD, A., \& ABEDINI, A. (2011). Proper Strategies for the Improvement and Renovation of the Worn Out Textures of Sirous District in Tehran Using SWOT Technique. Geography and Environmental Planning, 40(4), 65-88.

AMINI HOSSEINI, K., HOSSEINI, M., IZADKHAH, Y. O., MANSOURI, B., \& SHAW, T. (2014). Main challenges on community-based approaches in earthquake risk reduction: Case study of Tehran, Iran. International Journal of Disaster Risk Reduction, 8, 114-124. https://doi. org/10.1016/j.ijdrr.2014.03.001

ANDERSON, M. R. (2010). Community Psychology, Political Efficacy, and Trust. Political Psychology, 31(1), 59-84. https://doi.org/10.1111/j.1467-9221.2009.00734.x

AZIMI, M. (2016). Resolutions of the Supreme Council of Urban Planning and Architecture of Iran (M. Azimi (ed.); fourth edi).

BAGLIN, J. (2014). Improving Your Exploratory Factor Analysis for Ordinal Data: A Demonstration Using FACTOR. Practical Assessment, Research and Evaluation, 19(5). 
CHAVIS, D. M., \& WANDERSMAN, A. (1990). Sense of Community in the Urban Environment: A Catalyst for Participation and Community Development. In A Quarter Century of Community Psychology (Vol. 18, Issue 1, pp. 265-292). Springer US. https://doi.org/10.1007/978-1-44198646-7_14

COSTELLO, A. B., \& OSBORNE, J. W. (2005). Best practices in exploratory factor analysis: Four recommendations for getting the most from your analysis. Practical Assessment, Research and Evaluation, 10(7). https://doi.org/https://doi.org/10.7275/jyj1-4868

DATTALO, P. (2008). Determining sample size : balancing power, precision, and practicality. Oxford University Press.

FATEHELAHI, E. (2016). Tehran Earthquake and Urban Deteriorated Areas Summit Report.

FENG, Z., CRAMM, J. M., JIN, C., TWISK, J., \& NIEBOER, A. P. (2020). The longitudinal relationship between income and social participation among Chinese older people. SSM - Population Health, 11, 100636. https://doi.org/10.1016/j.ssmph.2020.100636

FERNÁNDEZ-MARTíNEZ, J. L., GARCÍA-ESPÍN, P., \& JIMÉNEZ-SÁNCHEZ, M. (2020). Participatory Frustration: The Unintended Cultural Effect of Local Democratic Innovations. Administration \& Society, 52(5), 718-748. https://doi.org/10.1177/0095399719833628

FIELD, A. (2009). discovering statistics using SPSS (third edit). SAGE Publications Ltd.

FONT, J., \& NAVARRO, C. (2013). PERSONAL EXPERIENCE AND THE EVALUATION OF PARTICIPATORY INSTRUMENTS IN SPANISH CITIES. Public Administration, 91(3), n/a-n/a. https://doi.org/10.1111/j.1467-9299.2012.02106.x

FONT, J., SMITH, G., GALAIS, C., \& ALARCON, P. (2018). Cherry-picking participation: Explaining the fate of proposals from participatory processes. European Journal of Political Research, 57(3), 615-636. https://doi.org/10.1111/1475-6765.12248

FRANK E. HARRELL, J. (2015). Regression Modeling Strategies (Second Edi). Springer. https:// doi.org/10.1007/978-3-319-19425-7

FUNG, A. (2003). Survey Article: Recipes for Public Spheres: Eight Institutional Design Choices and Their Consequences. Journal of Political Philosophy, 11(3), 338-367. https://doi. org/10.1111/1467-9760.00181

GESTHUIZEN, M. (2006). How Socially Committed are the Dutch Low-Educated? Historical Trends, Life-Course Changes, and Two Explanations for Educational Differences. European Sociological Review, 22(1), 91-105. https://doi.org/10.1093/esr/jci045

GHANBARI, Y., HOVASIN, N. M., \& JAMINI, D. (2012). Spatial Analysis and Classification of Women 's Employment Indices in Rural Areas of Iran. American Journal of Scientific Research, 71, 74-83. http://www.eurojournals.com/ajsr.htm

HAKIM, M., \& ROSHANALI, F. (2018). regeneration: An approach to strengthen the social infrastructure of deteriorated areas. Journal of Urban Regeneration and Renewal, 11(2), 266277.

HASANZADE, M., NIKPUR, A., \& LOTFI, S. (2018). Spatial analysis of economic poverty in Ghaemshahr. Journal of Geographical New Studies, Architecture and Urbanism, 2(13), 147168.

HAYS, R. A., \& KOGL, A. M. (2007). Neighborhood Attachment, Social Capital Building, and Political Participation: A Case Study of Low- and Moderate-Income Residents of Waterloo, lowa. Journal of Urban Affairs, 29(2), 181-205. https://doi.org/10.1111/j.1467-9906.2007.00333.x 
HO, R. (2006). Handbook of Univariate and Multivariate Data Analysis and Interpretation with SPSS (first edit). Chapman \& Hall/CRC.

JOBSON, J. D. (1992). Applied Multivariate Data Analysis. In S. Fienberg \& I. OJkin (Eds.), Journal of the Royal Statistical Society. Series A (Statistics in Society) (Vol. 156, Issue 3). Springer New York. https://doi.org/10.1007/978-1-4612-0921-8

KAISER, H. F. (1970). A second generation little jiffy. Psychometrika, 35(4), 401-415. https:// doi.org/10.1007/BF02291817

KANG, N., \& KWAK, N. (2003). A Multilevel Approach to Civic Participation. Communication Research, 30(1), 80-106. https://doi.org/10.1177/0093650202239028

KASARDA, J. D.; JANOWITZ, M. (1974). Community Attachment in Mass Society. American Sociological Review, 39(3), 328-339.

KHAEF, S., \& ZEBARDAST, E. (2016). Assessing Quality of Life Dimensions in Deteriorated Inner Areas: A case from Javadieh Neighborhood in Tehran Metropolis. Social Indicators Research, 127(2), 761-775. https://doi.org/10.1007/s11205-015-0986-6

KITCHIN, R., \& THRIFT, N. (2009). INTERNATIONAL ENCYCLOPEDIA OF HUMAN GEOGRAPHY (First edit). Elsevier.

LANCEE, B., \& VAN DE WERFHORST, H. G. (2012). Income inequality and participation: A comparison of 24 European countries. Social Science Research, 41(5), 1166-1178. https:// doi.org/10.1016/j.ssresearch.2012.04.005

LEACH, W. D., PELKEY, N. W., \& SABATIER, P. A. (2002). Stakeholder partnerships as collaborative policymaking: Evaluation criteria applied to watershed management in California and Washington. Journal of Policy Analysis and Management, 21(4), 645-670. https://doi. org/10.1002/pam.10079

MATHER, W. G. (1941). Income and Social Participation. American Sociological Review, 6(3), 380. https://doi.org/10.2307/2086195

MCMILLAN, D. W., \& CHAVIS, D. M. (1986). Sense of community: A definition and theory. Journal of Community Psychology, 14(1), 6-23. https://doi.org/10.1002/15206629(198601)14:1<6::AID-JCOP2290140103>3.0.CO;2-I

NABATCHI, T., \& AMSLER, L. B. (2014). Direct Public Engagement in Local Government. The American Review of Public Administration, 44(4_suppl), 63S-88S. https://doi. org/10.1177/0275074013519702

NASERI, E., \& SAFARI, B. (2018). Structural Causes of Unsuccessful Urban Regeneration: The Case of Renovation of Atabak Neighborhood in Tehran, Iran. In M. Chudoba \& J. Rajaniemi (Eds.), RE-CITY (pp. 83-102). School of Architecture Tampere University of Technology.

PAPADOPOULOS, Y., \& WARIN, P. (2007). Are innovative, participatory and deliberative procedures in policy making democratic and effective? European Journal of Political Research, 46(4), 445-472. https://doi.org/10.1111/j.1475-6765.2007.00696.x

PAULSEN, R. (1991). Education, Social Class, and Participation in Collective Action. Sociology of Education, 64(2), 96. https://doi.org/10.2307/2112881

QADEER, M. A. (1996). An Assessment of Pakistan's Urban Policies, 1947-1997. The Pakistan Development Review, 35(4), 443-465.

RAFIEIAN, M., \& MOHAMMADI AYDOGHMISH, F. (2016). Efficiency of Asset-Based Community Development Approach in Revitalization of Deteriorated Neighborhoods (The Case of Tehran, Emamzadeh Hassan Mohalla. The International Journal of Humanities, 23(3), 52-69. 
REMESAR, Antoni. (2020). "Co-design of public spaces with local communities". In Tony Bovaird and Elke Loeffler (ed) The Palgrave Handbook of Co-Production of Public Services and Outcomes (First on-line 24/11/2020, pp. 335-351). Palgrave Macmillan. https://doi. org/10.1007/978-3-030-53705-0_17

SANOFF, H. (2000). Community Participation Methods in Design and Planning. John Wiley \& Sons.

SCHARF, T., PHILLIPSON, C., \& SMITH, A. E. (2005). Social exclusion of older people in deprived urban communities of England. European Journal of Ageing, 2(2), 76-87. https://doi. org/10.1007/s10433-005-0025-6

SCHARPF, F. (1999). Governing in Europe: Effective and Democratic? In Governing in Europe: Effective and Democratic? Oxford University Press. https://doi.org/10.1093/ acprof:oso/9780198295457.003.0001

SEN, A. (1983). POOR, RELATIVELY SPEAKING *. Oxford Economic Papers, 35(2), 153-169. https://doi.org/10.1093/oxfordjournals.oep.a041587

SHAH, N. (2013). Literacy Rate in India. International Journal of Research in All Subjects in Multi Languages, 1(7), 12-16. http://www.indiaonlinepages.com/population/literacy-rate-inindia.html

SHAMAI, S. (1991). Sense of place: an empirical measurement. Geoforum, 22(3), 347-358. https://doi.org/10.1016/0016-7185(91)90017-K

SHIRVANI, H. (1985). The urban design process. Van Nostrand Reinhold.

Statistical yearbook of Tehran: Tehran City Statistics 2019. (2020). Information and Communication Technology Organization of Tehran Municipality. data.tehran.ir

TALÒ, C., MANNARINI, T., \& ROCHIRA, A. (2014). Sense of Community and Community Participation: A Meta-Analytic Review. Social Indicators Research, 117(1), 1-28. https://doi. org/10.1007/s11205-013-0347-2

TOOTOONCHI, S., \& MALEKAFZALI, A. A. (2019). The role of sustainable urban management in regenerating the deteriorated urban areas - an overview. Journal of Research in Ecology, 6(1), 1528-1533. http://ecologyresearch.info/ documents/EC0670.pdf

TRACY, J. L., TRABUCCO, A., LAWING, A. M., GIERMAKOWSKI, J. T., TCHAKERIAN, M., DRUS, G. M., \& COULSON, R. N. (2018). Random subset feature selection for ecological niche models of wildfire activity in Western North America. Ecological Modelling, 383(January 2018), 52-68. https://doi.org/10.1016/j.ecolmodel.2018.05.019

ULBIG, S. G. (2008). Voice is Not Enough. Public Opinion Quarterly, 72(3), 523-539. https:// doi.org/10.1093/poq/nfn030

WARNER, P. (2008). Ordinal logistic regression. Journal of Family Planning and Reproductive Health Care, 34(3), 169-170. https://doi.org/10.1783/147118908784734945

WILCOX, D. (1994). Community participation and empowerment : putting theory into practice. RRA Notes, 21, 78-82.

WU, F. (2012). Neighborhood Attachment, Social Participation, and Willingness to Stay in China's Low-Income Communities. Urban Affairs Review, 48(4), 547-570. https://doi. org/10.1177/1078087411436104

ZHANG, W., \&WU, Y. Y. (2017). Individual educational attainment, neighborhood-socioeconomic contexts, and self-rated health of middle-aged and elderly Chinese: Exploring the mediating 
role of socialand self-rated health of middle-aged and elderly Chinese: Exploring the mediating role of social engagement. Health \& Place, 44(May 2016), 8-17. https://doi.org/10.1016/j. healthplace.2016.12.006

\section{Received: $23 / 02 / 2021 \quad$ Evaluated: $30 / 03 / 2021$}

\section{(c) Saeed Najd Ataei Sarkarabad}

Email: sna85urb@gmail.com

University of Kurdistan, Department of Urban Planning and Design

Orcid https://orcid.org/0000-0003-1399-6516

Master's Degree in Urban Development Engineering-Urban Planning

Urban and Regional Planner Works as Project manager / Urban and Regional Planning Expert

in Maab Consulting Engineering / Urban and Regional Planning Company, Iran

\section{(c) Elahe Rezaei}

Email: ela87urb@gmail.com

Islamic Azad University, Science and Research Branch, Tehran, Department of Urban Planning Orcid https://orcid.org/0000-0003-4285-0292

Master's Degree in Urban Development Engineering-Urban Planning

Urban and Regional Planner. Works as Project manager in Urban Planning and Architecture

Research Center of Iran / Urban and Regional Planning Company, Iran

\section{(C) Kyoumars Habibi}

University of Kurdistan, Department of Urban Planning and Design

habibi_ki@yahoo.co.uk

Orcid https://orcid.org/0000-0002-7093-9625

PHD in Urban Planning. Associate Professor in Department of Urban Planning and Design, Faculty of Art and Architecture, University of Kurdistan (Iran)

\section{Acknowledgment}

This paper has been extracted from the information of the first author's master degree's dissertation "Review and Evaluate the Performance of Neighborhood Renovation Service Offices in Improving Residents' Participation in Urban Deteriorated Areas (Case Study: Fallah \& Yaftabad NeighbourhoodsDistrict 17 of Tehran Municipality)" done in 2013 at the University of Kurdistan under the direction of Dr. Kyoumars Habibi (Associate Professor). We want to thanks everyone who helped us in collecting and updating data for the dissertation and the current paper, especially the experts in the NRSO of Fallah \& Yaftabad neighbourhoods. 